\title{
Improving Ventilation and Saving Energy: Relocatable Classroom Field Study Interim Report
}

\section{September 2005}

Michael G. Apte, Ian S. Buchanan, David Faulkner, Toshifumi Hotchi, Michael

Spears, Douglas P. Sullivan, and Duo Wang

Indoor Environment Department

Environmental Energy Technologies Division

Lawrence Berkeley National Laboratory

This research was sponsored by the California Energy Commission through the Public Interest Energy Research program as the Lawrence Berkeley National Laboratory Classroom HVAC: Improving Ventilation and Saving Energy research project, CEC Contract Number 500-03-041. The study was additionally supported by the Assistant Secretary for Energy Efficiency and Renewable Energy, Building Technology Program of the U.S. Department of Energy under contract DE-AC02-05CH11231. 
Improving Ventilation and Saving Energy: Relocatable Classroom Field Study Interim Report

\section{Table of Contents}

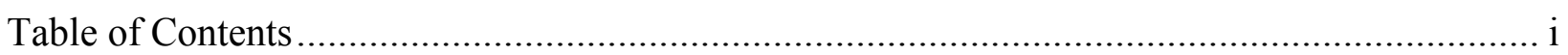

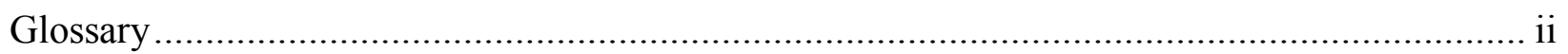

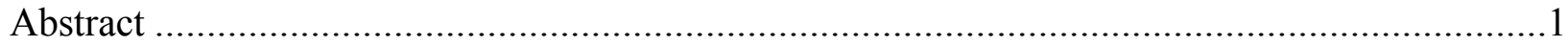

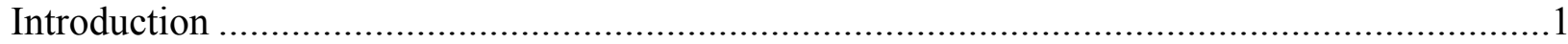

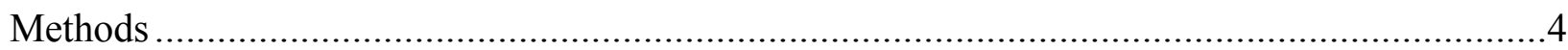

Field Study Plan ..........................................................................................

School Recruitment .......................................................................................... 4

Improved HPAC system installation and RC HVAC commissioning .................................5

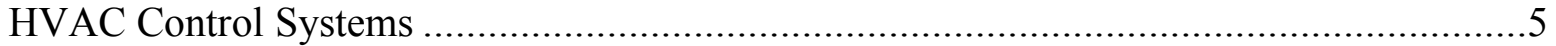

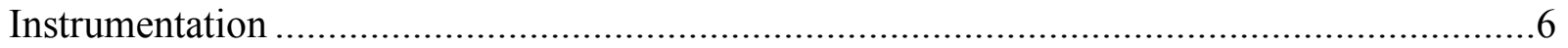

Measurements of air supply and ventilation........................................................ 6

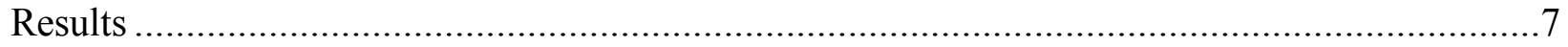

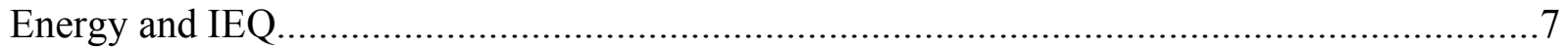

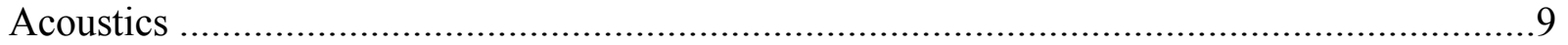

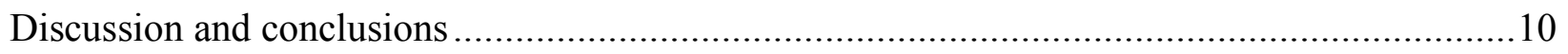

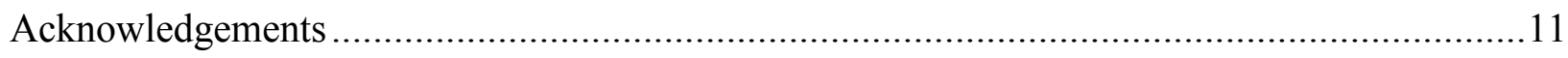

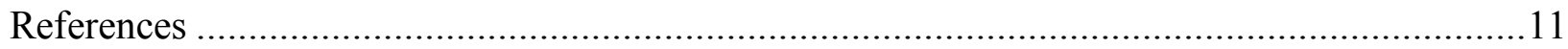

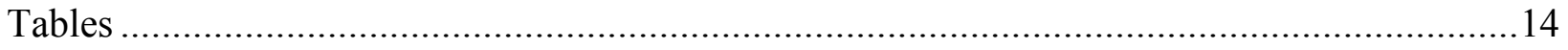

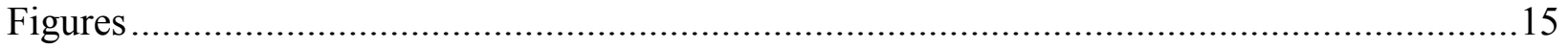


Improving Ventilation and Saving Energy: Relocatable Classroom Field Study Interim Report

\section{Glossary}

Specific terms and acronyms used throughout this report are defined as follows:

\begin{tabular}{|l|l|}
\hline Acronym & Definition* \\
\hline ASHRAE & American Society of Heating, Refrigeration, and Air Conditioning Engineers \\
\hline Bard & Bard Manufacturing Company \\
\hline CEC & California Energy Commission \\
\hline CFM & Cubic feet per minute, a measure of ventilation rate per occupant \\
\hline $\mathrm{CO}_{2}$ & Carbon dioxide \\
\hline $\mathrm{dB}(\mathrm{A})$ & A-weighted decibels, measurement of noise level \\
\hline $\mathrm{DOE}$ & United States Department of Energy \\
\hline $\mathrm{GP}$ & Geary Pacific Supply \\
\hline HVAC & Heating, ventilation, and air conditioning system \\
\hline IEQ & Indoor air and environmental quality \\
\hline IVSE & Classroom HVAC: Improving Ventilation and Saving Energy \\
\hline L & Liters \\
\hline LBNL & Lawrence Berkeley National Laboratory \\
\hline RC & Relocatable, or portable or modular, classroom \\
\hline RH & Relative humidity, measured as percentage \\
\hline RMS & Root Mean Square \\
\hline SEER & Seasonal energy efficiency rating \\
\hline T & Temperature, measured in degrees Celsius or Fahrenheit \\
\hline VOC & Volatile Organic Compounds \\
\hline
\end{tabular}




\begin{abstract}
The primary goals of this research effort are to develop, evaluate, and demonstrate a very practical HVAC system for classrooms that consistently provides classrooms with the quantity of ventilation in current minimum standards, while saving energy, and reducing HVAC-related noise levels. This research is motivated by the public benefits of energy efficiency, evidence that many classrooms are under-ventilated, and public concerns about indoor environmental quality in classrooms. This report presents an interim status update and preliminary findings from energy and indoor environmental quality (IEQ) measurements in sixteen relocatable classrooms in California. The field study includes measurements of HVAC energy use, ventilation rates, and IEQ conditions. Ten of the classrooms were equipped with a new HVAC technology and six control classrooms were equipped with a standard HVAC system. Energy use and many IEQ parameters have been monitored continuously, while unoccupied acoustic measurements were measured in one of four planned seasonal measurement campaigns. Continuously monitored data are remotely accessed via a LonWorks ${ }^{\circledR}$ network and stored in a relational database at LBNL. Preliminary results are presented here.
\end{abstract}

\title{
Introduction
}

The primary objectives of the "Improving Ventilation and Saving Energy" (IVSE) project were to develop, evaluate, and demonstrate a very practical HVAC system for relocatable classrooms (RCs) that consistently provides them with the quantity of ventilation in current minimum standards, while saving energy, and reducing HVAC-related noise levels. The ultimate goal is to provide the specification of this system to the public domain, and stimulate increased use of advanced classroom HVAC in the market through interaction with key school facility stakeholders.

The need for an improved classroom ventilation system is based, in part, on the considerable evidence, summarized in Daisey et al. (1998, 2003), indicating that ventilation rates in classrooms often do not meet the current ASHRAE minimum rate of 15 CFM per occupant (ASHRAE, 2004a). While relatively few measurements of actual classroom ventilation rates are available, concentrations of $\mathrm{CO}_{2}$ in classrooms often substantially exceeded $1000 \mathrm{ppm}$; implying ventilation rates less than 15 CFM per occupant, with several studies reporting peak concentrations exceeding $1500 \mathrm{ppm}$, and some concentrations exceeding $3000 \mathrm{ppm}$. In a recent survey of California portable classrooms (also called relocatable classrooms or RCs), $\mathrm{CO}_{2}$ concentrations exceeded $1000 \mathrm{ppm}$ in about $40 \%$ of classrooms and concentrations exceeded $2000 \mathrm{ppm}$ in approximately 10\% of classrooms (CARB-DHS 2003). In a survey of 400 classrooms in Washington state and Idaho (Shendell et al. 2004), $\mathrm{CO}_{2}$ concentrations measured at random times in $45 \%$ of classrooms exceeded $1000 \mathrm{ppm}$. Since some of these measurements occurred soon after occupancy a considerably larger fraction of steady state or peak $\mathrm{CO}_{2}$ concentrations would be expected to have exceeded 1000 ppm later in the school day.

Further evidence of low classroom ventilation rates was obtained in a study in 14 California schools (Lagus Applied Technologies 1995). The measured mean minimum air exchange rate was $2.4 \mathrm{~h}^{-1}$, with a range of 1.2 to $2.9 \mathrm{~h}^{-1}$, while the air exchange rate corresponding to the current standard was estimated to be $3 \mathrm{~h}^{-1}$. 
Improving Ventilation and Saving Energy: Relocatable Classroom Field Study Interim Report

Anecdotally, we are aware that ventilation rates in classrooms are often low because teachers frequently operate classroom HVAC systems in the mode where the supply fan shuts off except when heating or cooling is required. Thus, outside air is supplied mechanically only during periods of heating or cooling and the time average rate of supply is below standards. We also observe that teachers use this mode of HVAC system operation to avoid HVAC system-related noise. These anecdotal reports are supported by the findings from the recently completed survey of California RCs. Teachers in $60 \%$ of RCs reported that they sometimes turned off HVAC systems to reduce noise levels (CARB-CDHS 2003). Consequently, the available evidence indicates the importance of reducing HVAC noise in the development of improved classroom HVAC systems.

Several statutes and standard address the provision of adequate ventilation in California classrooms. Continuous ventilation is required in California Classrooms under both state energy and occupational laws (CA Title 24 2001, CCR 1995) and is a required component of ASHRAE Standard 62.1 (ASHRAE 2004a).

The relocatable classroom (RC) HVAC industry has been incrementally addressing the classroom noise levels generated by the wall mount heat pump air conditioner (HPAC) that they produce. For example, in the late 1990s Bard Manufacturing Company developed a 12 SEER "Quiet Climate" model to meet specifications from the Los Angeles Unified School District (LAUSD, 1998). This unit was designed to operate at indoor sound levels $\leq 50 \mathrm{~dB}(\mathrm{~A})$ measured at a point $3 \mathrm{~m}\left(10^{\prime}\right)$ from the return grille and $1.5 \mathrm{~m}$ high. This model is the current state of the art, with a relatively small market penetration in California and elsewhere. Unfortunately, 50 $\mathrm{dB}(\mathrm{A})$ is not currently considered an adequate target for classroom sound levels. The Collaborative on High Performance Schools (CHPS) recommends unoccupied classroom levels to be at or below $45 \mathrm{~dB}(\mathrm{~A})$ (CHPS 2002). Additionally, the Acoustical Society of America (ASA) provide a guideline for classrooms of $35 \mathrm{~dB}(\mathrm{~A})$ (ASA 2002).

A great deal of energy is used to condition ventilation air in high occupancy spaces such as classrooms. Mudarri et al. (1996) used an energy simulation model and estimated that increasing school building ventilation rates by $10 \mathrm{CFM}$, from 5 to $15 \mathrm{CFM}$ per occupant, would increase annual HVAC energy use by $15 \%, 31 \%$, and $32 \%$ in Miami, Washington, DC, and Seattle, respectively. From these predictions, we can estimate that the energy to provide 15 CFM per student of ventilation is approximately $22 \%, 45 \%$, and $45 \%$ of total classroom HVAC energy in these three climates, respectively. This finding indicates the existence of a clear energy and financial penalty from increasing ventilation to meet existing standards if improved energy efficiency is not applied to offset the increased demand.

A number of studies (e.g., Seppanen et al. 1999, Wargocki et al. 2002; Erdmann et al. 2002) have investigated the relationship of ventilation rates to health outcomes (sick building syndrome symptoms, respiratory illnesses), absence rates, and perceived air quality; however, most studies have been performed in office buildings. Some studies have used indoor $\mathrm{CO}_{2}$ concentrations as a surrogate for ventilation rate per occupant. A large majority of these studies have found a worsening of some health, absence, or perceived air quality outcomes at lower ventilation rates or higher $\mathrm{CO}_{2}$ concentrations. Detrimental effects have been particularly clear when ventilation rates are reduced below $20 \mathrm{CFM}$ per occupant and several studies have found benefits of 
Improving Ventilation and Saving Energy: Relocatable Classroom Field Study Interim Report

increasing ventilation rates above 20 CFM per occupant. These studies indicate that ventilation rates have important effects on the health of occupants.

When we consider these factors together - the important effects of ventilation on people, the energy used for ventilation, and the evidence of ventilation deficiencies in classrooms, it is very clear that we need to develop and promote use of highly energy efficient systems for providing classroom ventilation. To this end, an improved heat pump air conditioner (IHPAC) HVAC system was designed and fabricated. The prototype IHPAC was the product of specification of improvements to address IEQ and energy efficiency needs by LBNL, and design, in-house testing and refinement, and fabrication of a prototype design by Bard Manufacturing. The IHPAC was extensively tested at LBNL for energy efficiency, control of ventilation, and acoustic noise output, and suitability as a retrofit or new construction replacement for RCs. This research was conducted in an RC test bed facility at LBNL, and the results have been presented in detail in a previous report (Apte et al. 2005).

The laboratory-testing project involved the installation and verification of the performance of an IHPAC system, and its comparison, a standard HVAC system having an efficiency of 10 SEER. Points of verification included the checking that physical characteristics of the IHPAC system suitable for direct replacement of existing 10 SEER systems, quantitative demonstration of improved energy efficiency, reduced acoustic noise levels, quantitative demonstration of improved ventilation control, and verification that the system would meet temperature control demands necessary for the thermal comfort of the occupants (ASHRAE 2004b). Results showed that the IHPAC met these goals. The IHPAC was found to be a direct bolt-on replacement for the 10 SEER system. Calculated energy efficiency improvements based on many days of classroom cooling or heating showed that the IHPAC system was about 44\% more efficient during cooling and 38\% more efficient during heating than the 10 SEER system. Noise reduction was dramatic, with measured A-weighed sound level for fan only operation conditions of $34.3 \mathrm{~dB}(\mathrm{~A})$, a reduction of $19 \mathrm{~dB}(\mathrm{~A})$ compared to the 10 SEER system. Similarly, the IHPAC stage- 1 and stage- 2 compressor plus fan sound levels were $40.8 \mathrm{~dB}(\mathrm{~A})$ and $42.7 \mathrm{~dB}(\mathrm{~A})$, reductions of 14 and $13 \mathrm{~dB}(\mathrm{~A})$, respectively. Thus, in these tests the IHPAC was 20 to 35 times quieter than the 10 SEER systems depending upon the operation mode. The IHPAC system met the ventilation requirements and was able to provide consistent outside air supply throughout the study. Indoor $\mathrm{CO}_{2}$ levels with simulated occupancy were maintained below 1000 ppm. Finally temperature settings were met and controlled accurately. The goals of the laboratory testing phase were met and the system was found to be acceptable and ready for further study in a field test of occupied classrooms.

The objectives of this field study are to evaluate the energy, ventilation, and IEQ performance of the IHPAC HVAC system when deployed in occupied classrooms and to perform a highly visible demonstration of the system. Although highlights of study methods are presented here, a detailed field study design and methods description was reported earlier (Apte et al. 2004) that should be referred to for complete information on how the field study has been conducted.

During this field study some parameters are measured in real time (continuously or every 1 to 30 minutes) and periodic measurements (once per season) are made for other parameters.

Parameters measured in real time include indoor and outdoor temperature and humidity, HVAC power, and indoor and outdoor carbon dioxide concentrations. Parameters measured periodically 
Improving Ventilation and Saving Energy: Relocatable Classroom Field Study Interim Report

include concentrations of formaldehyde and other volatile organic compounds, particle concentrations, noise levels, and ozone concentrations.

The objectives of the data evaluation are to quantify how the advanced HVAC system influences: a) HVAC operation periods; b) HVAC energy use; c) ventilation rates; d) noise levels; e) pollutant concentrations and f) thermal comfort.

\section{Methods}

\section{Field Study Plan}

The IHPAC system was installed in six relocatable classrooms, called intervention (also described as "Experimental" classrooms in some Figures). Six matched control classrooms were also selected. The control classrooms were matched with intervention classrooms by location (school), grade level, manufacturer, and classroom age. Each intervention RC was located exactly next door to a control RC. In addition to the six RC pairs, an additional four RCs were equipped with an IHPAC at the same school sites, but were studied less intensively. Instrumentation systems were installed in each intervention and control classroom and HVAC energy performance and IEQ are to be monitored over an entire year of school. The benefits of the advanced HVAC system are quantified by comparing the measured data from the intervention and control classrooms, using statistical models to adjust for imperfect matching to the degree possible. In this interim report of the field study the RCs have been monitored for about 7 months, and one site visit for detailed IEQ monitoring was completed.

\section{School Recruitment}

Criteria for school selection were based upon climate, and geography. Northern and Southern California locations were selected for broader representation of the state. The San Joaquin Valley was selected for cold winter and hot summers, and the San Bernardino Valley was selected for the high cooling demand and long cooling season. Schools were selected and recruited for this study in early 2004. Recruitment of participant schools was accomplished through two mechanisms. In the case of the Modesto City Schools in Northern California, we contacted the Facilities Manager directly as LBNL had previously conducted research in the district and had a working relationship with them. In the case of San Bernardino, Geary Pacific Supply, the California Distributor of Bard HVAC equipment provided a list of potential school districts in the Southern CA region to LBNL. Contact letters were sent to a number of school district facilities managers in the region and site visits were conducted to those districts that expressed interest in participating. The Fontana Unified School District was found to meet the needs of the study and was therefore selected. Principals from two schools in each district were contacted with the assistance of their facilities managers, and were found to be willing to host the research in their schools.

RCs in each school were assessed for their potential to be studied as a set where some would be used as controls and some would receive the HVAC system upgrade with the advanced systems. Each school had to have a group of RCs, preferably sited in a row, equipped with 10 SEER Bard HVAC systems, and in at least pairs with the same year of manufacture. It was preferred that the RCs were at most 10 years old. Additionally if they had a known or suspected IAQ problem they would not be acceptable. 
Improving Ventilation and Saving Energy: Relocatable Classroom Field Study Interim Report

\section{Improved HPAC system installation and RC HVAC commissioning}

Ten IHPAC systems were shipped from Bard Manufacturing factory to Northern and Southern CA branches of Geary Pacific Corp. GP installed, with the assistance of local HVAC contractors, the HVAC systems and associated ducting, registers, and controls in all ten study RCs. GP also commission the advanced systems and re-commissioned the existing HVAC systems in the matched control RCs. Commissioning included setting of the outdoor air supply rates at 465 CFM (15 CFM per occupant), replaced air filters, balanced supply registers, and verified proper functioning of controls.

\section{HVAC Control Systems}

The HVAC systems in the Control RCs were left for the teachers to operate using the existing standard thermostat coupled with an existing standard twist-type four-hour shutoff timer. The operation of this thermostat is entirely under the control of the teachers, and sometimes the school custodians at the beginning or end of the day. The thermostat has an automatic mode where it heats or cools according to setpoint, providing ventilation and air circulation only when thermal conditioning is required. An additional manual setting on the thermostat allows the teacher to turn on the fan independently if desired, allowing for continuous ventilation. However, as discussed above, this option is seldom used consistently due to the additional noise produced when the air supply fan is operating. The expectation in leaving them "as-is" is that the thermostats in the Control RCs would be used in the typical fashion during the study, and if questioned, the teachers have been advised that they should follow their school district policy for HVAC operation.

In the RCs equipped with the IHPAC systems, an automatic "smart controller" was provided. This controller was been developed by Bard Manufacturing for the IHPAC system as part of this project. It is designed to relieve the responsibility of the teachers of the majority of HVAC operation tasks. Additionally, it decouples the ventilation and thermal aspects of control through the use of an internal motion-detector-type occupancy sensor that triggers ventilation whenever occupants are detected. The teacher's control interface is limited to a simple temperature setting adjustment, using up-arrow and down-arrow buttons to provide a locked indoor temperature range (field settable by a technician, and set to $\pm 4.0^{\circ} \mathrm{F}\left(2.5^{\circ} \mathrm{C}\right)$ in this study) in order to accommodate individual comfort differences. The modified temperature setting reverts to the baseline setting after twelve hours. The occupancy sensor logic is set to wait 30 minutes after the last observed motion in the RC before setting back the temperature and shutting down the ventilation. It is also desensitized to very short (i.e., one-minute) detection of motion to avoid unneeded operation, but triggers HVAC operation as soon as a valid occupancy is detected. Finally, the system is designed to learn the classroom occupancy schedule over a moving twoweek period, and then start anticipating occupancy by pre-conditioning the RC to the settings learned from the teacher's temperature control use patterns. Pre-conditioning also includes a pre-occupancy ventilation purge of three air changes (roughly one hour) as required by California Title 24 (CEC 2001, 2005). An additional benefit of this control system is that it has a digital electronic interface configured to operate on a LonWorks ${ }^{\circledR}$ (www.echelon.com) network, allowing remote access for monitoring and control of all of the thermostat and HVAC functions. 
Improving Ventilation and Saving Energy: Relocatable Classroom Field Study Interim Report

\section{Instrumentation}

The instrumentation used in this field study is shown in Table 1. Real-time data are stored as 6minute averages or totals. Total RMS power consumption is measured on each HVAC system using WattNode ${ }^{\mathrm{TM}}$ (Continental Control Systems, Bolder CO, www.wattnode.com) power meters. Indoor and outdoor temperature, $\mathrm{RH}$, and $\mathrm{CO}_{2}$ concentrations are measured for each $\mathrm{RC}$ continuously. Indoor and outdoor particle, aldehydes, VOCs, and ozone concentrations in the RCs are monitored once a season during site visits. Classroom acoustic noise with the HVAC system operating during occupied and unoccupied periods are also measured during the seasonal site visits in each $\mathrm{RC}$.

Indoor and outdoor temperature and $\mathrm{RH}$ are monitored primarily using the sensors in the PureChoice Nose ${ }^{\mathrm{TM}}$ (PureChoice Inc., Lakeview, MN). This device is connected to an i.Lon 100 network, and is be accessible on the internet by the researchers 24 hours a day.

$\mathrm{CO}_{2}$ is measured using two different systems; the Fuji ZPF-9 has been used by LBNL for many years as a standard method in buildings. In this study a PureChoice Nose ${ }^{\mathrm{TM}} \mathrm{CO}_{2}$ sensor has been installed in each RC. The sensors differ in stated accuracy, and the Fuji unit samples with a pump, while the PureChoice sensor samples using gas diffusion. The PureChoice sensor is factory-calibrated and expected to maintain accuracy specifications for five years. The Fuji units is calibrated at least once a season during site visits and an automatic calibration check system is run in situ once a week. Both systems are connected to the i.Lon 100 network and are accessible on the internet by the researchers 24 hours a day.

Site visits to the schools occur at least once per season in order to check and calibrate instrumentation, to characterize indoor and outdoor concentrations of particles, VOCs, aldehydes, and ozone, and to conduct acoustical measurements. Classroom ventilation rates are measured during unoccupied periods using $\mathrm{CO}_{2}$ decays. Real-time data from the particle, sound level meter, and thermal comfort carts are downloaded onto a laptop computer for subsequent analysis. $\mathrm{CO}_{2}$ decay data are monitored using the existing monitors installed in each $\mathrm{RC}$. Similarly, the VOC, aldehyde, and ozone sampling media are transported to LBNL for subsequent laboratory analysis.

\section{Measurements of air supply and ventilation}

Outside air supply flowrates and supply register flowrates were measured using an active flow hood method (Walker et al. 2001) developed at LBNL. The same process was applied to measure the outside air intake flow and the return flow. Outside air supply rates (outside air is about $30 \%$ of the total supply air in this recirculating system) was set to 15 CFM per occupant, or 465 CFM for a class of 30 students and one teacher. The three supply registers were balanced to split the total supply flow equally (about 500 CFM per register).

$\mathrm{RC}$ air exchange rates have been measured using a tracer decay method. $\mathrm{CO}_{2}$ decays were measured with the installed $\mathrm{CO}_{2}$ monitors, and the air exchange rate was calculated after subtracting the outdoor $\mathrm{CO}_{2}$ concentration. During seasonal site visits, additional $\mathrm{CO}_{2}$ decays with the HVAC system ventilation fans on were conducted. This was achieved by injecting $\mathrm{CO}_{2}$ from a cylinder into the unoccupied rooms until a concentration of approximately $2000 \mathrm{ppm}$ was reached. After allowing the $\mathrm{CO}_{2}$ to decay to background levels, the air exchange rate was 
Improving Ventilation and Saving Energy: Relocatable Classroom Field Study Interim Report

calculated as the negative slope of the logarithm of the indoor minus outdoor tracer concentration during the tracer decay.

\section{Results}

\section{Energy and IEQ}

Real time monitoring data in the study RCs were collected 24 hours per day, seven days a week. The data that are discussed below are a subset of those available in the IVSE database. In particular, they are restricted to the school day hours - 08:00 to 16:00. The purpose of this restriction is twofold. First, for clearer summarization and comparison between classrooms, averaging in data during un-occupied periods merely obscure the conditions that occur during the school day. A second reason is to avoid confusion caused by a problem that occurred during the earlier part of the Winter data collection. This problem, discussed in Apte et al. 2005, was that certain software settings in the IHPAC smart controller caused the system to start preconditioning the $\mathrm{RC}$ temperature hours prior to morning occupancy, driving up energy consumption during the night. The problem was solved after several winter weeks and the software was upgraded. No nighttime unoccupied heating occurred after this time.

Figures 1-9 present distributions of calculated daily school day monitoring statistics of indoor and outdoor temperature, relative humidity, indoor-outdoor (delta) $\mathrm{CO}_{2}$ concentrations, and daily school day HVAC energy use and HVAC power consumption during winter (partial), spring, and summer (partial) seasons. In these figures the Intervention RCs are described as "Experimental" classrooms - these terms may be considered synonymous for the purpose of this report. The data shown in Figures 1-3 (winter season) will be discussed in some detail as a point in case, while the highlights of the other seasons will follow as the basic patterns are similar. This interim report does not attempt to provide exact quantitative results, but rather allows for a qualitative comparison of IEQ conditions and energy consumption characteristics in the intervention and control RCs. In the box and whisker plots shown in these figures, the distribution average and median values are depicted as a "+" and the inner-box horizontal line, respectively. The lower and upper horizontal lines of the boxes represent the first and third quartile values, and the bottom and top whiskers represent the $10^{\text {th }}$ and $90^{\text {th }}$ percentile values of the distributions. Further exploration of the details and comparisons of daily summary statistics from ongoing collection of field data may be found on the project website at eetd.lbl.gov/ied/ivse.

Figure 1 shows the distribution of wintertime school-day average classroom and outside temperatures and relative humidities. The very tight indoor temperature ranges and similar central tendencies indicate that both the 10 SEER and IHPAC systems maintained similar indoor temperatures around $72.5^{\circ} \mathrm{F}\left(22.5^{\circ} \mathrm{C}\right)$. School day average outdoor temperatures were somewhat cooler in the northern California schools than in the south although even the coolest average temperatures were not extreme. Indoor relative humidity was on average slightly lower in the intervention RCs in the northern CA RCs, and about equal in all RCs in the south, although the averages were all in the $45 \%$ to $55 \% \mathrm{RH}$ range. There was far more variability in daily average indoor RH in the south than in the north, and the intervention RCs in the south had the greatest variability, ranging from about $15 \% \mathrm{RH}$ to almost $75 \% \mathrm{RH}$. The greater variability in indoor $\mathrm{RH}$ in the intervention RCs during the heating season is likely due to the continuous supply of outdoor air ventilation that caused the indoor RH to track the outdoor levels. 
Indoor-outdoor (delta) $\mathrm{CO}_{2}$ levels during the winter are shown in Figure 2. It should be noted that these data include all classrooms on all school days, and in some cases the classrooms were unoccupied. Small measurement differences between indoor and outdoor average $\mathrm{CO}_{2}$ concentrations could lead to negative values in the extremes of the distributions, as is seen in the figure. Average delta $\mathrm{CO}_{2}$ values for the intervention classrooms in both regions were about 150 to $250 \mathrm{ppm}$, while those for the control classrooms from about 600 to $1200 \mathrm{ppm}$. Outdoor $\mathrm{CO}_{2}$ concentrations averaged around $400 \mathrm{ppm}$. Thus on average, the control classroom indoor $\mathrm{CO}_{2}$ concentrations were typically above $1000 \mathrm{ppm}$. The $90^{\text {th }}$ percentile of average delta $\mathrm{CO}_{2}$ levels were well below $1000 \mathrm{ppm}$ in the intervention classrooms, while the top $10 \%$ of control intervention classroom deltas were greater than about $1800 \mathrm{ppm}$ in the north and about $2500 \mathrm{ppm}$ in the southern California RCs. In order to take a look at more extreme levels during the schoolday, the $99^{\text {th }}$ percentile delta concentrations are shown as well. Although in some cases in the Intervention classrooms peak delta $\mathrm{CO}_{2}$ levels were elevated, on average the control $\mathrm{RC}$ delta peaks were about $2000 \mathrm{ppm}$ in the north and $1400 \mathrm{ppm}$ in the south. It is clear from these data that the continuous outside air ventilation supplied by the IHVAC during occupied periods makes a tremendous difference in removing indoor contaminants.

Figure 3 presents measured school day energy consumption and average and peak $\left(95^{\text {th }}\right.$ percentile) power use during the winter season. As would be expected during the heating season, less energy was consumed and less power demand occurred in the south. Average energy use was relatively similar between the 10 SEER and IHVAC systems in both the north (about $3 \mathrm{kWh}$ per day) and south (about $2 \mathrm{kWh}$ per day). In the north, the variability of daily energy consumption was almost exactly the same between the two systems. This was not so in the south, where the schoolday 10 SEER HVAC use was dramatically skewed towards zero energy use. In this warmer climate (about $25 \%$ of average daytime temperature $>70^{\circ} \mathrm{F}$ ), the 10 SEER system was not operated at all on many days with little detriment to comfort from the temperature standpoint. Remember that the IHPAC control system operates the heat pump to achieve the thermal setpoint whenever it observes occupancy - this strategy may cause thermal conditioning to be provided before the occupants really feel the need for it. Of course as discussed in the introduction, 10 SEER non-operation is also likely to be due to the acoustic noise conditions that occurs when the fan and or compressor is in operation.

The $95^{\text {th }}$ percentile power consumption statistics shown in Figure 3 indicate that peak power consumption of the IHPAC is considerably lower than that of the 10 SEER system. The daytime average power use is consistent with the energy consumption, as would be expected. The peak power demand of the IHPAC is about 0.8 and 0.6 of the peak power demand of the 10-SEER system for the northern and southern sites, respectively, based on comparisons of the $90^{\text {th }}$ percentile whiskers of the $95^{\text {th }}$ percentile IHPAC power use charts. These ratios are not inconsistent with the $38 \%$ greater efficiency of the IHPAC observed for heating in the laboratory phase of this study (Apte et al. 2005).

Indoor temperatures during spring season are roughly the same as during the winter. Indoor $\mathrm{RH}$ follows the same pattern as well including greater variability in the RCs with continuous ventilation. Outdoor temperatures have risen compared to Figure 1. Likewise, school day average delta $\mathrm{CO}_{2}$ concentrations continue to be much lower in the IHPAC RCs. Some higher peak $\left(99^{\text {th }}\right.$ percentile) delta $\mathrm{CO}_{2}$ concentrations are seen for the southern intervention RCs during this season. The problem, having been narrowed down to a faulty batch of outside air louver 
Improving Ventilation and Saving Energy: Relocatable Classroom Field Study Interim Report

motor, was subsequently identified and solved. Although not dramatically different, school day energy use was just slightly higher in the intervention RCs compared to the controls. Again, the peak power of the 10 SEER systems was higher in both regions.

Figures 7-9 follow the same pattern as above, but for summer season. Due to low classroom use during traditional summer vacation schedules in northern California, only southern data are shown in these figures. The intervention RCs were operated at several degrees lower temperature on average compared to the controls. Outside temperatures were often above $90^{\circ} \mathrm{F}$. Indoor RH levels were similar between the RC types, and were held within reasonable limits from a thermal comfort standpoint. Delta $\mathrm{CO}_{2}$ concentrations follow the same trend as in the other seasons. However, the peaks were not as high in the 10 SEER RCs as in the earlier seasons. No doubt, this is due to increased teacher operation of the HVAC system to meet real comfort needs, and increased compressor cycling to meet these needs - more outside air ventilation is provided in these classrooms when the demand for compressor cycling is higher.

Finally, the HVAC school day energy use was virtually the same for the two systems during the summer months (Figure 9). However, as before, the peak power consumption of the IHPAC was well below that of the 10 SEER system. The low $10^{\text {th }}$ percentile whiskers in these power plots are due to a couple of RCs with low use during the summer season.

\section{Acoustics}

Indoor sound pressure levels were measured during unoccupied periods in thirteen of the sixteen RCs in the study during May of 2005. Figure 10 shows the background level (all equipment including lights off) and with only the HVAC fan on in each RC. Sound levels were measured at four locations as discussed in the method section. As can be seen, in this mode, all of the IHPAC systems operated at noise levels below, or very slightly above $40 \mathrm{~dB}(\mathrm{~A})$ at the closest measurement point (10' $x 5^{\prime}$ '). The 10 SEER systems with fan on only were somewhat noisier with levels from about $42 \mathrm{~dB}(\mathrm{~A})$ to $55 \mathrm{~dB}(\mathrm{~A})$. The system measured in $\mathrm{S} 2$-Room 16 was considerably quieter in fan-only than any of the other 10 SEER units that were tested - the reason for this is not yet known. As expected the sound levels drop of as a function of distance from the wall with the return register (and HVAC) unit mounted on it.

Figure 11 shows the noise levels in 10 SEER RCs with compressor and fan on. Levels measured at $10^{\prime}$ x 5 ' ranged from about $52 \mathrm{~dB}(\mathrm{~A})$ to $56 \mathrm{~dB}(\mathrm{~A})$. Figure 12 shows similar measurements for the IHPAC RCs with the Stage-1 compressor and fan on. The target sound level maximum for the IHPAC is $45 \mathrm{~dB}(\mathrm{~A})$ or less at the $10^{\prime} \times 5^{\prime}$ position. Five of the seven units met this requirement in the Stage-1 mode, but two (S1-35 and S1-37) were slightly louder. Figure 13 shows the results for six of the IHPAC systems (data for S2-Room 17 missing) with the compressor in Stage-2 and fan on. In this case, the sound levels were somewhat louder than expected. None of the systems quite met the $45 \mathrm{~dB}(\mathrm{~A})$ target, although one was only slightly louder. The unit in S1-35 was excessively noisy in this test with a level of about $52 \mathrm{~dB}(\mathrm{~A})$. The reasons for the increased noise levels compared to those observed in the laboratory tests are under investigation, and the manufacturer is working on some additional improvements. The most likely explanation for the higher level of noise output is the construction of the $\mathrm{RC}$ wall, and the extent to which vibration can is transmitted into the room. Other explanations cannot be ruled out at this point. 
Improving Ventilation and Saving Energy: Relocatable Classroom Field Study Interim Report

\section{Discussion and conclusions}

In summary, the ten prototype IHPAC systems installed in these schools operated reliably, with only a couple of problems with the supply air louvers that were subsequently remedied. The systems provided similar thermal comfort (temperature and humidity) conditions to the control classroom 10 SEER units. Ventilation was vastly superior in the intervention classrooms. During fan-only operation the IHPAC is extremely quiet, and during compressor operation it is slightly noisier than expected based on the laboratory RC test bed measurements at LBNL. Nonetheless, the IHPAC clearly provides a significant improvement in indoor noise levels. It is anticipated that the acoustics will be improved further before the end of this project.

The energy consumption of the IHPAC-equipped RCs does not directly reflect the increased efficiency of the IHPAC units when energy use is compared to that in the Control RCs with 10 SEER systems. There are three reasons for this. First, the teacher-operators of the HVAC systems do not operate the 10 SEER units until they sense a need to adjust the room temperature, possibly a minimizing use pattern - this is in part because of the HVAC noise levels generated in these RCs. Second, the IHPAC system controls are programmed to condition to set-point as soon as they detect occupancy - this leads to a maximization of IHPAC space conditioning. Third, the continuous ventilation provided by the IHPAC system requires continuous conditioning of outside air with an energy penalty.

With these three reasons, important points must be made. First, when the teacher waits for discomfort as the cue to turn on the HVAC, the thermal comfort of the students, and accompanying attention to lessons may be affected. Second, as discussed in the introduction, ventilation standards for classrooms are written into California state energy and occupational law, so conditions where the ventilation fan systems are not on are likely to be in violation of theses statues. Third, also discussed in the introduction, evidence is mounting that conditions of poor ventilation are linked to increased absenteeism and respiratory disease transmission. Loss of classroom time is linked with poorer student achievement. The effects of poor ventilation on teacher performance and health are also in question.

This being said, the IHPAC is providing the ventilation required by California State law without an extra energy penalty. Additional benefits include lower noise that will enhance learning in the classroom, and better health and welfare for students and teachers. Looked at from a different perspective, to bring the existing classrooms up to the California State ventilation requirements and to meet ASHRAE 62.1 recommendations using the 10 SEER HVAC systems could increase current energy use by roughly 25 to 70 percent adding an additional burden on the power grid.

Finally, given the nature of the observed energy usage patterns of the IHPAC in this study some options exist for adjustment of the smart controls to further reduce unnecessary energy consumption, potentially enhancing the energy savings beyond the break-even conditions that have been observed during the first nine months of the study. First, the infrared occupancy sensor operates in a binary mode where full ventilation is supplied regardless of the number of occupants in the classroom. Although during class time the occupancy is usually near to the full class size, periods do exist during the day when only the teacher, or only a few students are present. An alternative strategy is to use a $\mathrm{CO}_{2}$ based demand control sensor, a mode that the IHPAC controller is designed to operate under. Using this approach excessive ventilation during 
Improving Ventilation and Saving Energy: Relocatable Classroom Field Study Interim Report

low occupancy periods will be reduced. Plans are in place to test this approach during the upcoming months.

A second strategy is to reconfigure the thermostat to allow the temperature to float unless the teacher activates a thermal conditioning timer set for a relatively short time period, perhaps three or four hours. This may be done without disrupting the automatic continuous ventilation supplied to the RC. The responsibility would be placed on the teacher to determine when to turn on the thermal conditioning, thus saving energy when he/she does not feel the need for it. The drawback to this approach is that it is possible that the indoor thermal comfort of the occupants may suffer. However, this is the thermal conditioning strategy used in many classrooms currently. Some variant of this approach will also be tested in the field in the upcoming months in order to maximize the energy savings potential of the IHPAC system.

\section{Acknowledgements}

This research was sponsored by the California Energy Commission through the Public Interest Energy Research program as the Lawrence Berkeley National Laboratory Classroom HVAC: Improving Ventilation and Saving Energy research project, CEC Contract Number 500-03-041. The study was additionally supported by the Assistant Secretary for Energy Efficiency and Renewable Energy, Office of Technology Development, Office of Building Technologies of the U.S. Department of Energy under contract DE-AC03-76SF00098. The authors would like to thank Echelon Corporation, Continental Control Systems, and PureChoice Inc. for their contributions of equipment and technical support for energy and IEQ monitoring in this study. We would also like to thank Bill Fisk and Ashok Gadgil of LBNL for their review of this manuscript.

\section{References}

M.G. Apte, D. Faulkner, A.T. Hodgson, D.P. Sullivan. 2004. Classroom HVAC: Improving Ventilation and Saving Energy Field Study Plan, LBNL-56267, Lawrence Berkeley Laboratory, University of California, Berkeley, CA 94720.

M.G. Apte, I.S. Buchanan, D. Faulkner, W.J. Fisk, C.M. Lai, M. Spears, and D.P. Sullivan. 2005. "Improving Ventilation and Saving Energy: Laboratory Study in a Modular Classroom Test Bed," LBNL-58577, Lawrence Berkeley Laboratory, University of California, Berkeley, CA 94720.

ASA 2002. "Acoustical Performance Criteria, Design Requirements, and Guidelines for Schools.” ANSI S12.60-2002. Acoustical Society of America. Melville, NY 11747

ASHRAE. American Society of Heating, Refrigerating, and Air Conditioning Engineers (ASHRAE). 2004. ANSI/ASHRAE 62, Ventilation for acceptable indoor air quality. Atlanta, GA, ASHRAE, Inc.

ASHRAE, 2004b. ANSI/ASHRAE 55-2004 ASHRAE standard, Thermal Environmental Conditions for Human Occupancy, Atlanta: American Society of Heating, Refrigerating and AirConditioning Engineers, Inc. 
Improving Ventilation and Saving Energy: Relocatable Classroom Field Study Interim Report

CEC. 2001, 2005. California Building Standards, Title 24-Energy Efficiency, part six. California Energy Commission, Sacramento, CA.

CARB/CDHS. 2003. "Report to the California Legislature. Environmental Health Conditions in California's Portable Classrooms." California Air Resources Board and the California Department of Health Services. Sacramento CA.

CCR 1995. California Code of Regulations, Occupational Safety and Health Codes for nonresidential buildings, Title 8, State of California, Sacramento, CA.

Collaborative for High Performance Schools (CHPS). 2002. "HVAC Best Practices Manual." CHPS Inc. http://www.chps.net/manual/index.htm, San Francisco, CA.

Daisey, J and Angell, WJ. A Survey and Critical Review of the Literature on Indoor Air Quality, Ventilation, and Health Symptoms in Schools. Berkeley, CA: Ernest Orlando Lawrence Berkeley National Laboratory, Environmental Energy Technologies Division, Indoor Environment Department, March 1998. LBNL-41517

Daisey, J.M., W.J. Angell, and M.G. Apte. Indoor Air Quality, Ventilation and Health Symptoms in Schools: An Analysis of Existing Information. Berkeley, CA: Ernest Orlando Lawrence Berkeley National Laboratory, Environmental Energy Technologies Division, Indoor Environment Department, 2003. Indoor Air, 13(1):53-64 (LBNL-48287).

Erdmann, C.A., Steiner, K.C, Apte, M.G., (2002) "Indoor carbon dioxide concentrations and SBS symptoms in office buildings revisited: Analyses of the 100 building BASE Study dataset". Proceedings of Indoor Air 2002 Conference, Monterey, CA, Vol. 3, pp. 443-448. Indoor Air 2002, Santa Cruz, CA

Lagus Applied Technologies. 1995. Air Change Rates in Non-Residential Buildings in California. Report P400-91-034BCN, Prepared for the California Energy Commission by Lagus Applied Technology, Inc., San Diego, California.

LAUSD. 1998. "LAUSD Specifications for Air Conditioning Systems (Wall Mount Heat Pump). Specifications data 7/5/98." Los Angeles Unified School District, Los Angeles CA.

Mudarri, D, Hall JD, and Werling E. 1996. Energy cost and IAQ performance of ventilation systems and controls. Proceedings of IAQ'96 Paths to Better Building Environments, pp 151160. ASHRAE, Atlanta, GA.

Seppanen, O.A., Fisk, W.J., and Mendell, M.J. (1999) Association of ventilation rates and $\mathrm{CO}_{2}$ concentrations with health and other human responses in commercial and institutional buildings. Indoor Air 9: 226-252.

Shendell DG, Prill R, Fisk WJ, Apte MG, Blake D, Faulkner D (2004) Associations between classroom $\mathrm{CO}_{2}$ concentrations and student attendance. Indoor Air, 14 (3) 333-41. 
Improving Ventilation and Saving Energy: Relocatable Classroom Field Study Interim Report

Wargocki P et al. (2002) Ventilation and health in non-industrial indoor environments: report from a European multidisciplinary scientific consensus meeting (EUROVEN). Indoor Air 12: 113-128.

Walker, I.S., Wray, C.P., Dickerhoff, D.J., and Sherman, M.H. 2001. Evaluation of flow hood measurements for residential register flows. LBNL-47382. Lawrence Berkeley National Laboratory, University of California, Berkeley, CA 94720. 


\section{Tables}

Table 1. The field study instrumentation.

\begin{tabular}{|c|c|c|c|}
\hline $\begin{array}{l}\text { Parameters } \\
\text { Measured }\end{array}$ & Instrument & Calibration method & $\begin{array}{l}\text { Data collection rate/ } \\
\text { acquisition method }\end{array}$ \\
\hline $\begin{array}{l}\text { Air } \\
\text { temperature }\end{array}$ & $\begin{array}{l}\text { Onset Instrument, HOBO-Pro Series Temp Ext } \\
\text { C loggers with a resolution of } 0.02{ }^{\circ} \mathrm{C} \text { and rated } \\
\text { accuracy of } \pm 0.2{ }^{\circ} \mathrm{C}\end{array}$ & $\begin{array}{l}\text { NIST-traceable RTD system } \\
\text { with } 0.02{ }^{\circ} \mathrm{C} \text { rated accuracy }\end{array}$ & $\begin{array}{l}\text { Real-time, internal data } \\
\text { logger-download } \\
\text { monthly }\end{array}$ \\
\hline $\begin{array}{l}\text { Relative } \\
\text { humidity }\end{array}$ & $\begin{array}{l}\text { Onset Instrument } \mathrm{HOBO} \AA \text { Temperature, } \mathrm{RH}(\mathrm{C} \\
\text { with rated accuracy of } \pm 3 \% \mathrm{RH}\end{array}$ & $\begin{array}{l}\text { Use of salt solutions to } \\
\text { produce air with various } \\
\text { reference values of humidity }\end{array}$ & $\begin{array}{l}\text { Real-time, internal data } \\
\text { logger - download } \\
\text { monthly }\end{array}$ \\
\hline $\begin{array}{l}\text { Carbon } \\
\text { dioxide } \\
\text { concentration }\end{array}$ & $\begin{array}{l}\text { California Analytical Instruments infrared } \\
\text { analyzer, ZPF-9, 0-3000 ppm range }\end{array}$ & $\begin{array}{l}\text { Cylinders of primary standard } \\
\text { calibration gases }\end{array}$ & $\begin{array}{l}\text { Real-time - data logged } \\
\text { to i.Lon } 100 \text { web server, } \\
\text { acquired continuously }\end{array}$ \\
\hline $\begin{array}{l}\text { Air } \\
\text { Temperature, } \\
\text { Relative } \\
\text { Humidity, } \\
\text { Carbon } \\
\text { Dioxide }\left(\mathrm{CO}_{2}\right)\end{array}$ & $\begin{array}{l}\text { PureChoice Nose TM. Temperature (resolution } \\
0.1^{\circ} \mathrm{C} \text {, rated accuracy } \pm 0.5^{\circ} \mathrm{C} \text { ), } \mathrm{RH} \text { (resolution } \\
1 \% \mathrm{RH} \text {, rated accuracy larger of } \pm 10 \% \text { or } \pm 5 \% \\
\mathrm{RH} \text { ), } \mathrm{CO}_{2} \text { range } 0-5000 \mathrm{ppm} \text { (resolution } 10 \\
\text { ppm, accuracy greater of } \pm 5 \% \text { or } 100 \mathrm{ppm} \text { ). }\end{array}$ & NIST-traceable calibrations & $\begin{array}{l}\text { Real-time - data logged } \\
\text { to i.Lon } 100 \text { web server, } \\
\text { acquired continuously }\end{array}$ \\
\hline $\begin{array}{l}\text { Ventilation } \\
\text { rate }\end{array}$ & $\begin{array}{l}\text { Tracer gas decay during unoccupied time using } \\
\text { sulfur hexafluoride }\left(\mathrm{SF}_{6}\right) \text {, or carbon dioxide } \\
\text { tracer gas. Tracers monitored using infrared } \\
\text { analyzers }\end{array}$ & $\begin{array}{l}\text { Cylinders of primary standard } \\
\text { calibration gases }\end{array}$ & $\begin{array}{l}\text { Measured once a season } \\
\text { per RC during site visits. } \\
\text { Real-time data collected } \\
\text { on laptop computer }\end{array}$ \\
\hline $\begin{array}{l}\text { Particle } \\
\text { concentration, } \\
\text { size } \\
\text { distribution }\end{array}$ & $\begin{array}{l}\text { Particle Measuring systems LASAIR Aerosol } \\
\text { Particle Counter or equivalent multi-channel } \\
\text { counter that detects particles as small as } 0.2 \\
\text { micrometer }\end{array}$ & $\begin{array}{l}\text { Factory calibration, and } \\
\text { intercomparison with other } \\
\text { aerosol instrumentation at } \\
\text { LBNL }\end{array}$ & $\begin{array}{l}\text { Measured once a season } \\
\text { per RC during site visits. } \\
\text { Real-time data collected } \\
\text { on laptop computer }\end{array}$ \\
\hline $\begin{array}{l}\text { Aldehyde } \\
\text { concentrations }\end{array}$ & $\begin{array}{l}\text { 7-hour aldehyde samples collected onto treated } \\
\text { silica-gel cartridges (WAT047205, Waters } \\
\text { Corp.) with sample flow rate of } 0.15 \mathrm{~L} / \mathrm{min} \text {. } \\
\text { Analysis by high performance liquid } \\
\text { chromatography with UV detection following } \\
\text { ASTM standard method D-5197-97 (ASTM, } \\
\text { 1997b). }\end{array}$ & $\begin{array}{l}\text { Sorbent tubes spiked with } \\
\text { known quantity of aldehydes }\end{array}$ & $\begin{array}{l}\text { Samples collected once a } \\
\text { season per RC during site } \\
\text { visits. Analyzed at } \\
\text { LBNL post sampling. }\end{array}$ \\
\hline $\begin{array}{l}\text { VOC } \\
\text { concentrations }\end{array}$ & $\begin{array}{l}\text { 7-hour VOC gas samples collected onto Tenax- } \\
\mathrm{TA}^{\mathrm{TM}} \text { sorbent tubes (CP-16251; Varian Inc.) } \\
\text { modified by substituting a } 15-\mathrm{mm} \text { section of } \\
\text { Carbosieve S-III } 60 / 80 \text { mesh }(10184 \text {, Supelco } \\
\text { Inc.) at the outlet end. Sample flow rate will be } \\
0.0051 / \text { min. VOC samples analyzed by thermal } \\
\text { desorption-gas chromatography/mass } \\
\text { spectrometry generally following U.S. EPA } \\
\text { Method TO-1 (U.S. EPA, 1984) }\end{array}$ & $\begin{array}{l}\text { Sorbent tubes spiked with } \\
\text { known quantity of VOCs }\end{array}$ & $\begin{array}{l}\text { Samples collected once a } \\
\text { season per RC during site } \\
\text { visits. Analyzed at } \\
\text { LBNL post sampling. }\end{array}$ \\
\hline $\begin{array}{l}\text { Ozone } \\
\text { concentrations }\end{array}$ & $\begin{array}{l}\text { 7-hour indoor and outdoor ozone passive } \\
\text { samplers (Ogawa 3300) with Ion } \\
\text { Chromatography (IC) analysis by IML Inc., } \\
\text { Sheridan WY. }\end{array}$ & $\begin{array}{l}\text { Nitrite to nitrate chemistry. } \\
\text { Nitrate standards used to } \\
\text { calibrate IC. }\end{array}$ & $\begin{array}{l}\text { Samples collected once a } \\
\text { season per RC during site } \\
\text { visits. Analyzed at IML } \\
\text { post sampling. }\end{array}$ \\
\hline Sound levels & $\begin{array}{l}\text { Sound spectrum meter for } \sim 6 \text { to } 20 \mathrm{~Hz} \text { spectrum } \\
\text { such as the Bruel and Kjaer model } 2260\end{array}$ & Factory calibration & $\begin{array}{l}\text { Measured once a } \\
\text { season/RC during site } \\
\text { visits, collected on laptop } \\
\text { computer }\end{array}$ \\
\hline $\begin{array}{l}\text { Power } \\
\text { Monitoring }\end{array}$ & $\begin{array}{l}\text { WattNode } \mathrm{TM} \text { datalogging line power monitor } \\
\text { measures true RMS power and energy } \\
\text { consumption- logged continuously. Current } \\
\text { measured with inductive current transducers } \\
\text { simultaneously with line voltage. Accuracy of } \\
\text { the WattNode } \mathrm{TM} \text { is } \pm 0.5 \% \text { of reading over } \\
\text { operating range. }\end{array}$ & Factory Calibration & $\begin{array}{l}\text { Real-time - data logged } \\
\text { to i.Lon } 100 \text { web server, } \\
\text { acquired continuously }\end{array}$ \\
\hline $\begin{array}{l}\text { Thermal } \\
\text { Comfort }\end{array}$ & $\begin{array}{l}\text { LBNL Thermal Comfort Cart. ASHRAE } \\
\text { Standard 55-2004. Measures air temperature, } \\
\text { mean radiant temperature, relative humidity, and } \\
\text { air velocity. }\end{array}$ & $\begin{array}{l}\text { Factory Calibration and } \\
\text { Calibration checks using } \\
\text { NIST-traceable methods }\end{array}$ & $\begin{array}{l}\text { Integrated datalogger } \\
\text { downloaded after } \\
\text { collection }\end{array}$ \\
\hline
\end{tabular}


Improving Ventilation and Saving Energy: Relocatable Classroom Field Study Interim Report

Figures
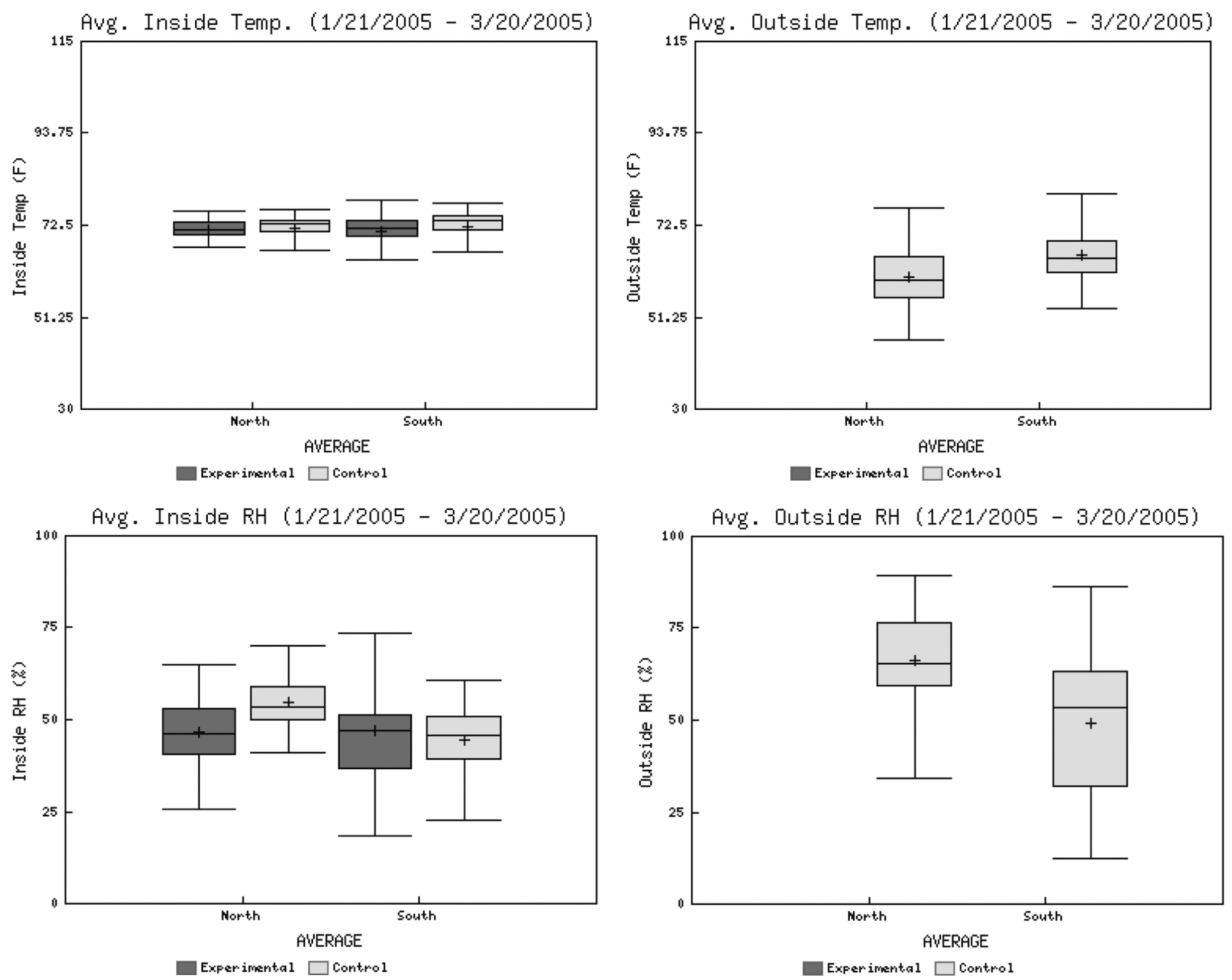

Figure 1. Box and whisker distributions of school day-average wintertime (January 21-March 20) indoor and outdoor temperature and relative humidity data for all four schools in the IVSE study. The data are aggregated by Experimental (IHPAC) and Control (10 SEER) classrooms and by northern and southern California school districts. See report text for explanation of box and whisker plot statistics. 

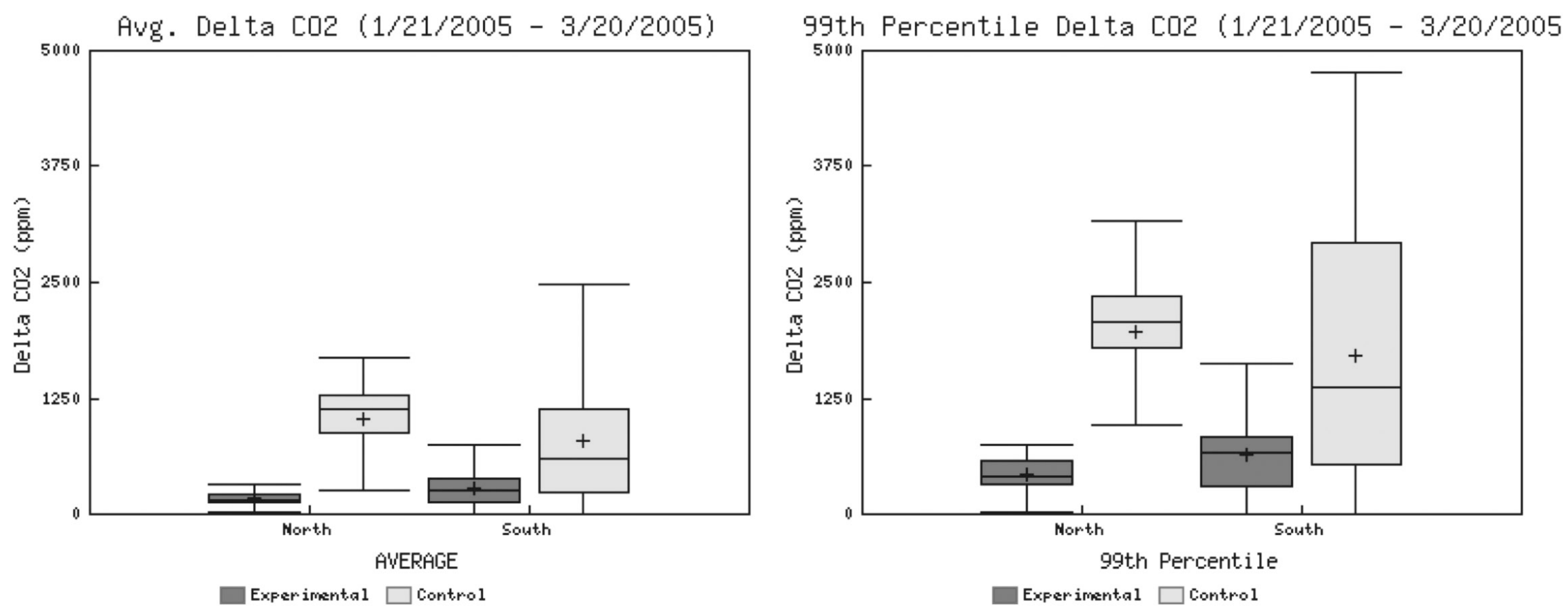

Figure 2. Box and whisker distributions of school day-average and $99^{\text {th }}$ daily percentile wintertime (January 21-March 20) indoor minus outdoor (delta) carbon dioxide data for all four schools in the IVSE study. The data are aggregated by Experimental (IHPAC) and Control (10 SEER) classrooms and by northern and southern California school districts. See report text for explanation of box and whisker plot statistics. 
Improving Ventilation and Saving Energy: Relocatable Classroom Field Study Interim Report

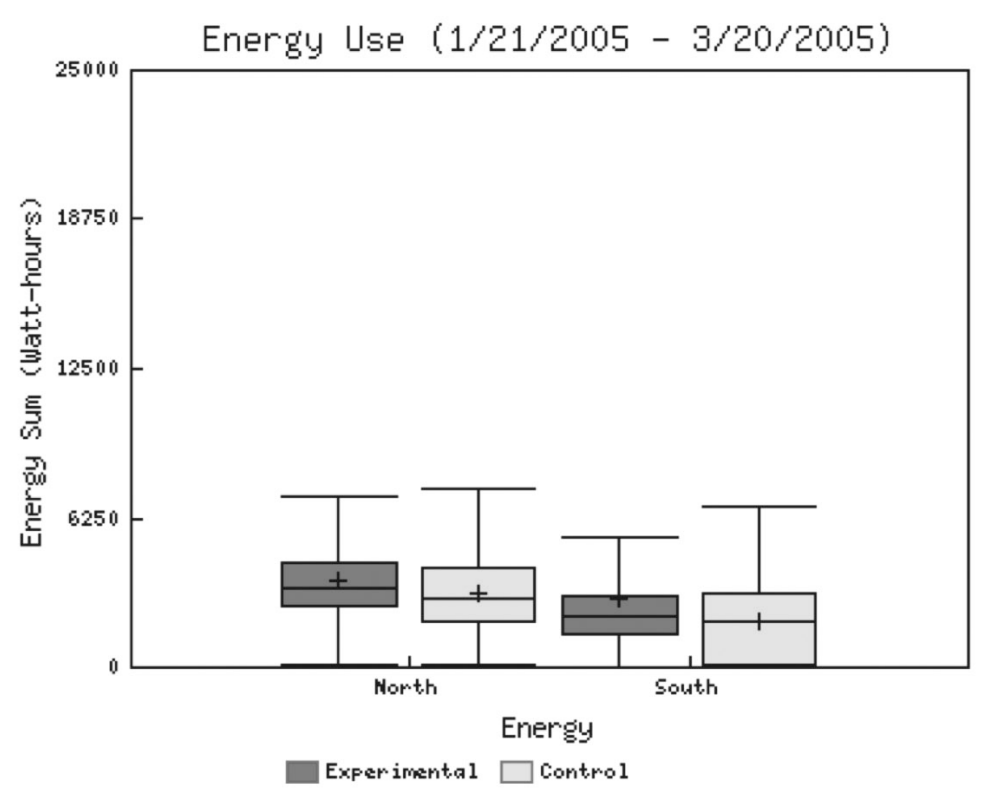

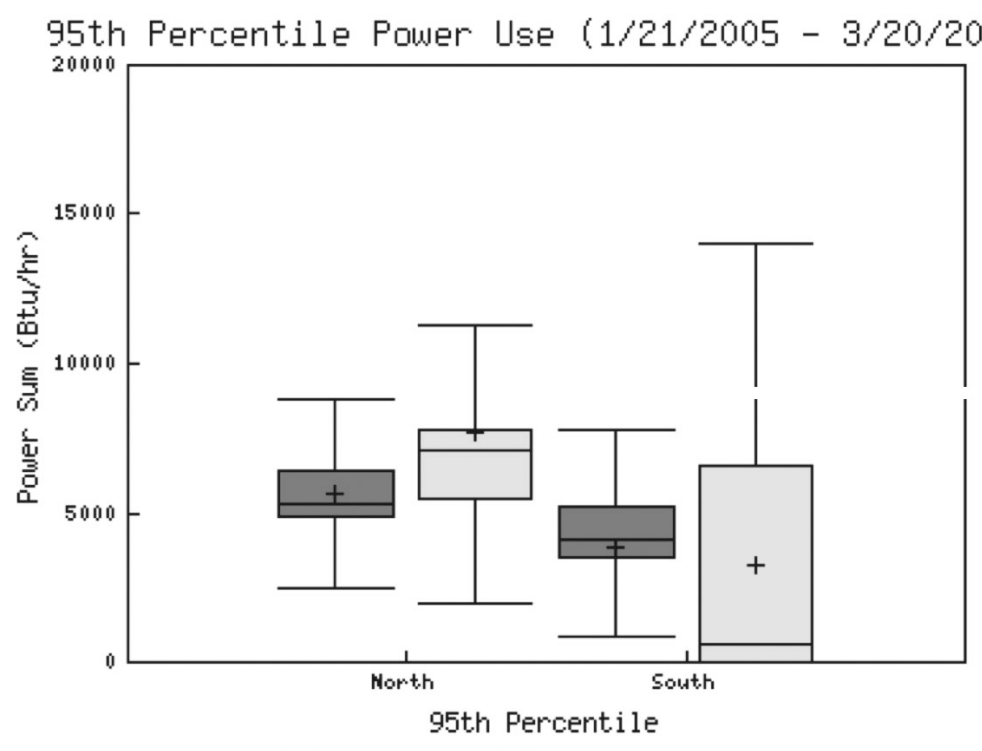

$\square$ Experimental $\square$ control

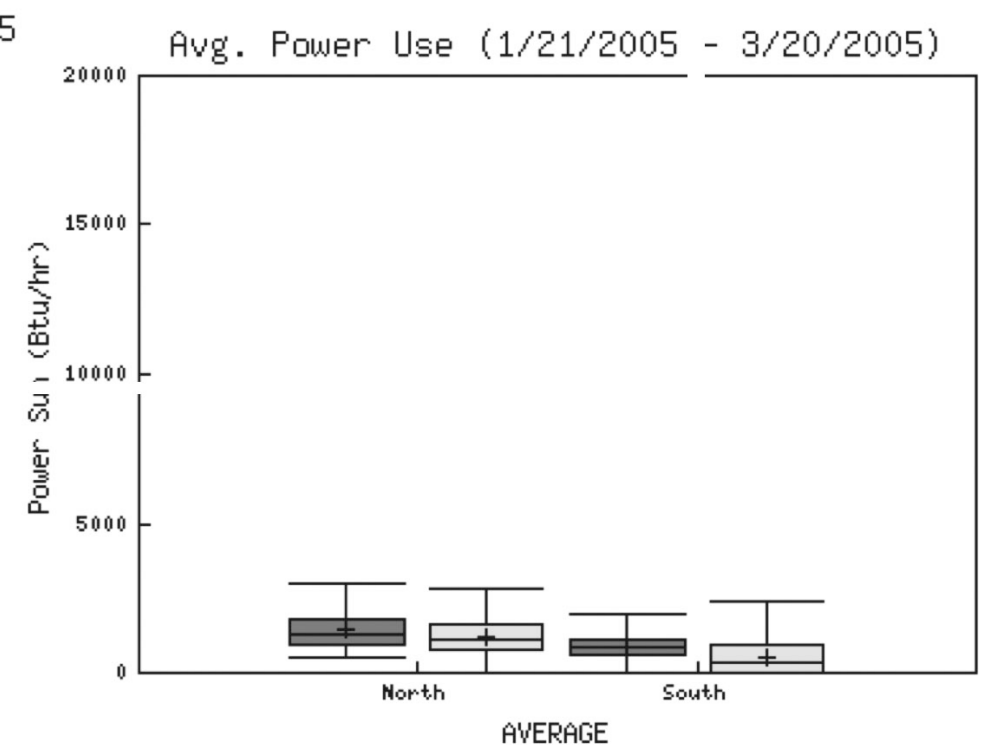

$\square$ Experiment,al $\square$ Cont,rol

Figure 3. Box and whisker distributions of school day-average wintertime (January 21-March 20) energy use and daily average and $95^{\text {th }}$ percentile HVAC power consumption for all four schools in the IVSE study. The data are aggregated by Experimental (IHPAC) and Control (10 SEER) classrooms and by northern and southern California school districts. See report text for explanation of box and whisker plot statistics. 

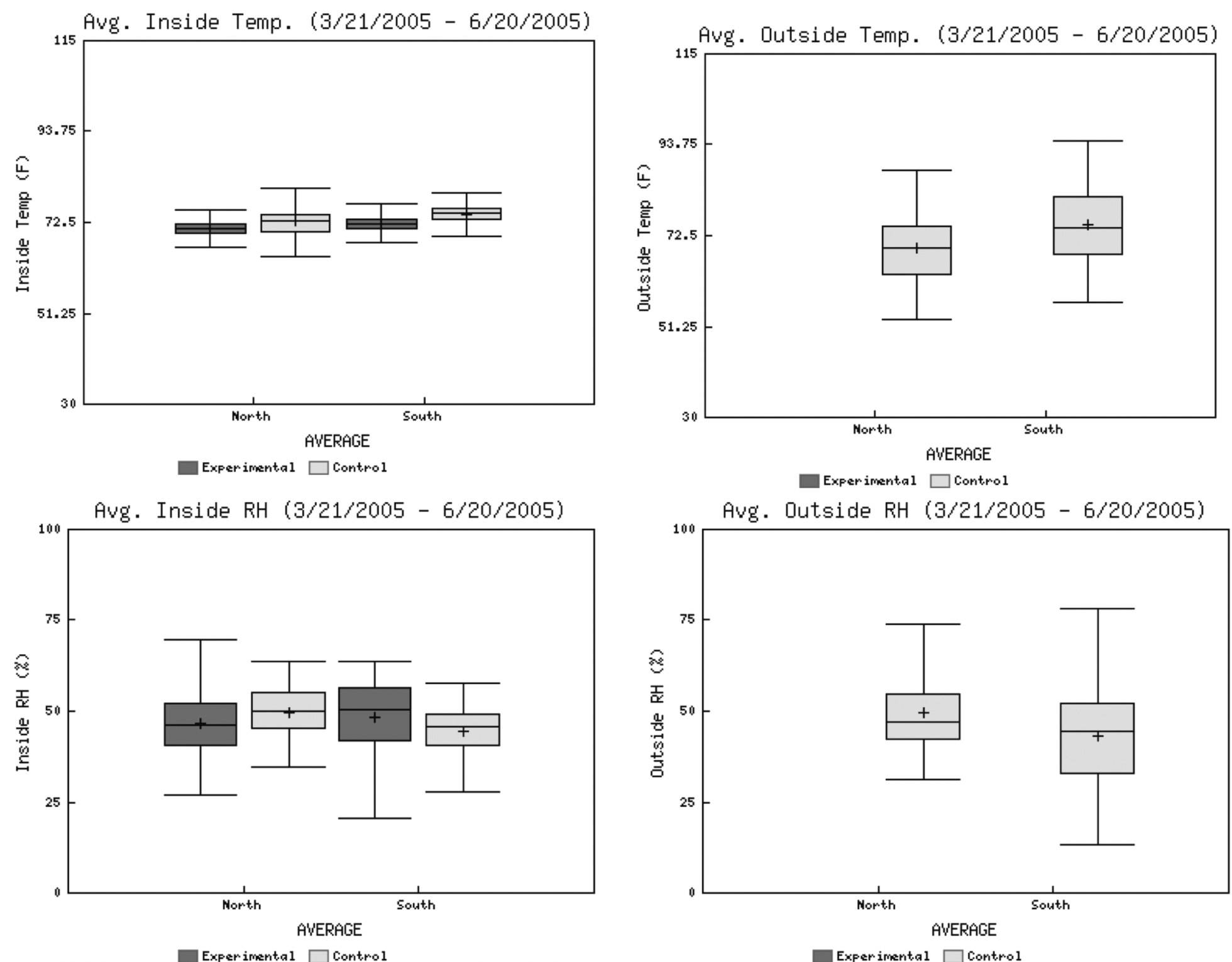

Figure 4. Box and whisker distributions of school day-average springtime (March 21-June 20) indoor and outdoor temperature and relative humidity data for all four schools in the IVSE study. The data are aggregated by Experimental (IHPAC) and Control (10 SEER) classrooms and by northern and southern California school districts. See report text for explanation of box and whisker plot statistics. 
Improving Ventilation and Saving Energy: Relocatable Classroom Field Study Interim Report
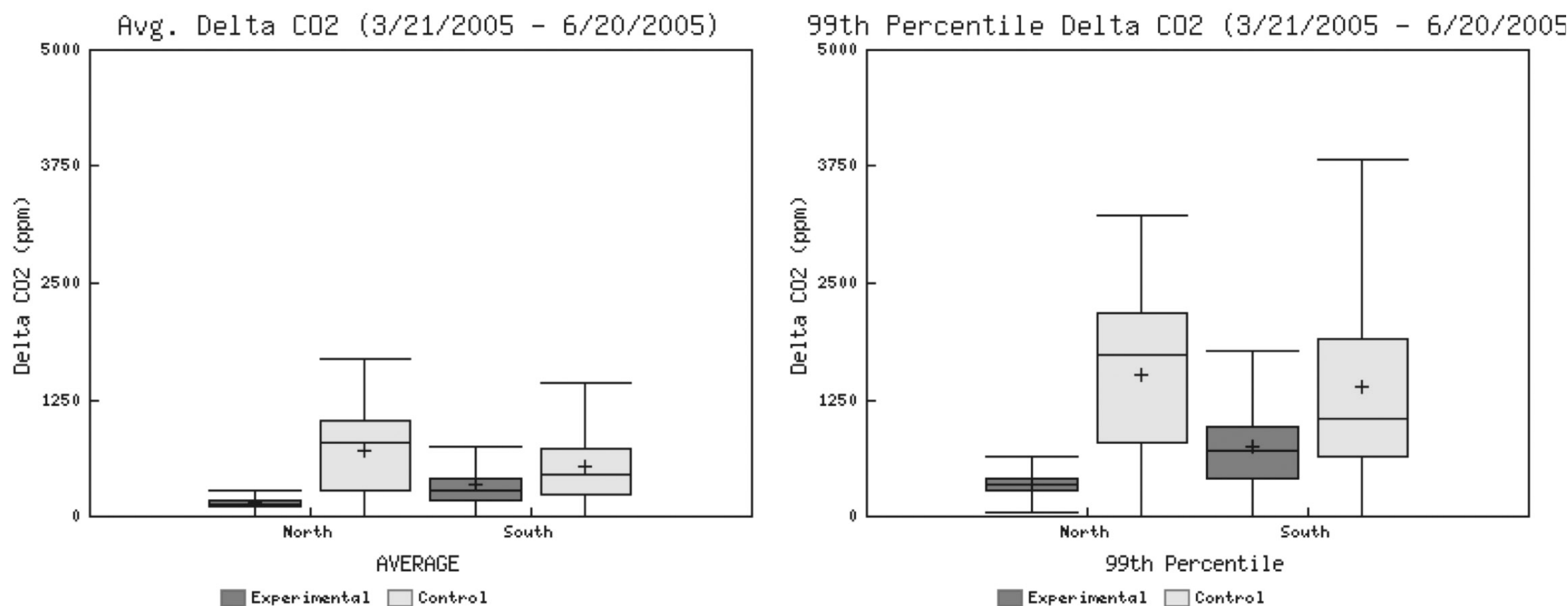

Figure 5. Box and whisker distributions of school day-average and $99^{\text {th }}$ daily percentile springtime (March 21-June 20) indoor minus outdoor carbon dioxide data for all four schools in the IVSE study. The data are aggregated by Experimental (IHPAC) and Control (10 SEER) classrooms and by northern and southern California school districts. See report text for explanation of box and whisker plot statistics. 
Improving Ventilation and Saving Energy: Relocatable Classroom Field Study Interim Report
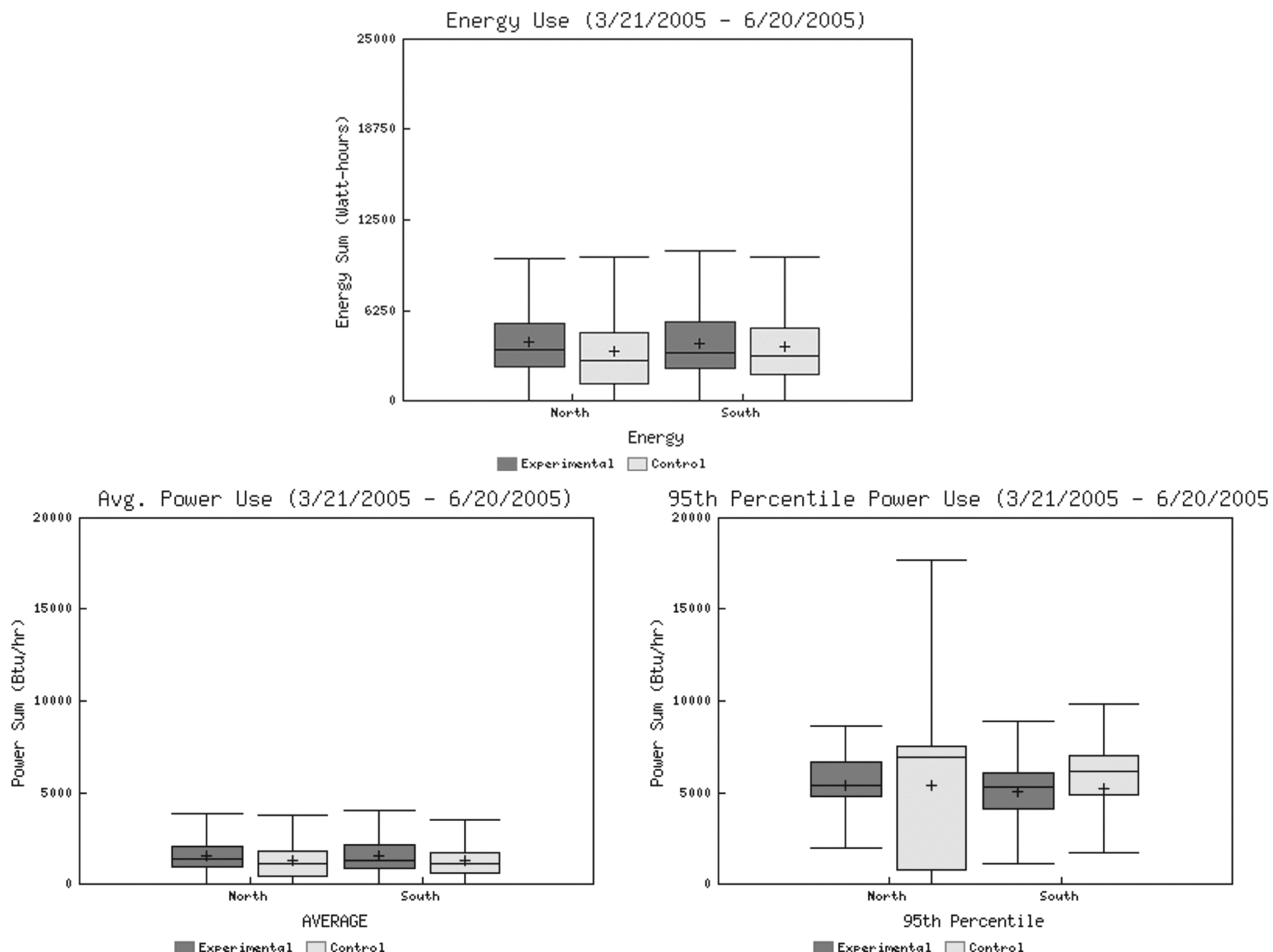

Figure 6. Box and whisker distributions of school day-average springtime (March 21-June 20) energy use and daily average and $95^{\text {th }}$ percentile HVAC power consumption for all four schools in the IVSE study. The data are aggregated by Experimental (IHPAC) and Control (10 SEER) classrooms and by northern and southern California school districts. See report text for explanation of box and whisker plot statistics. 
Improving Ventilation and Saving Energy: Relocatable Classroom Field Study Interim Report
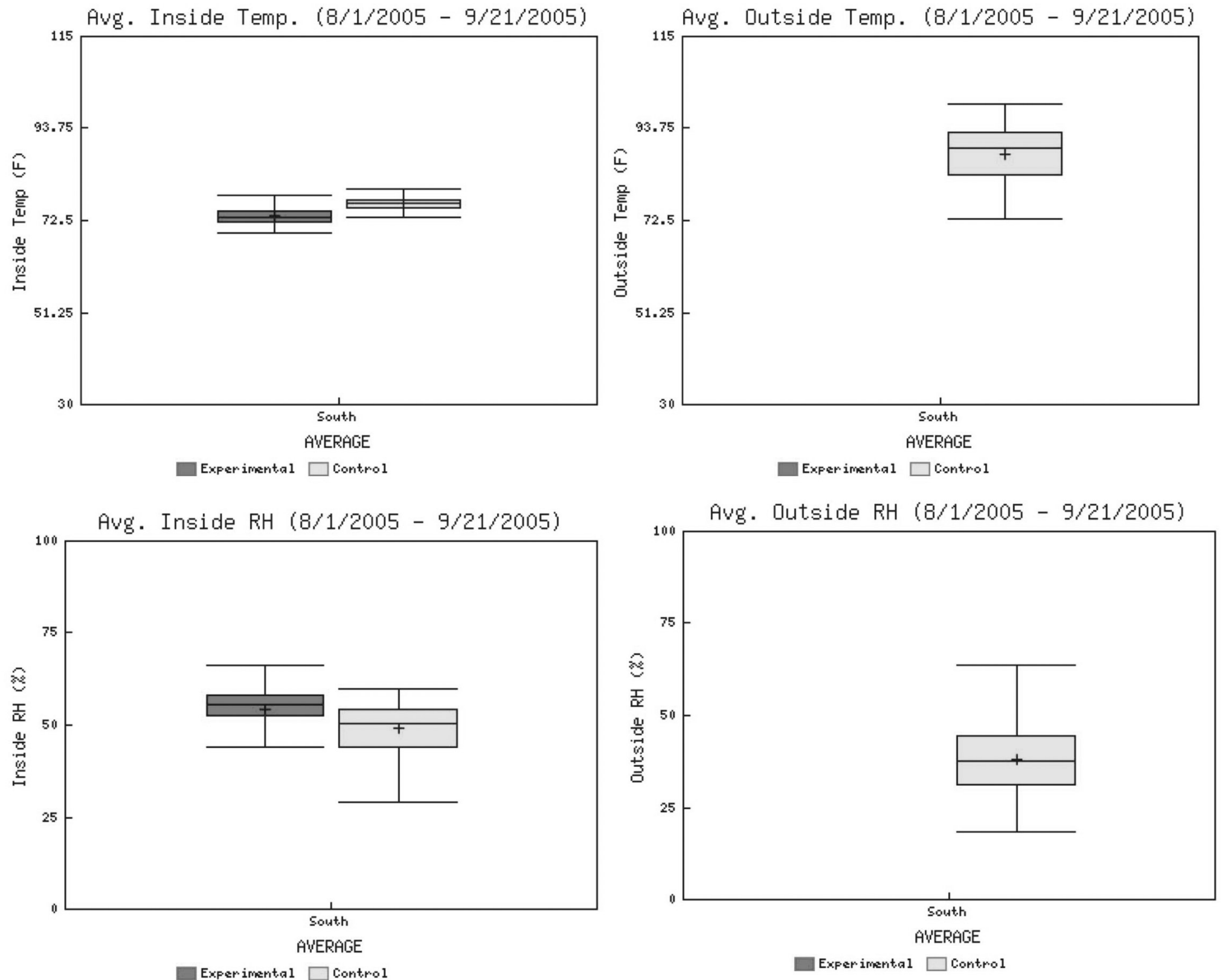

Figure 7. Box and whisker distributions of school day-average summertime (August 1-September 21) indoor and outdoor temperature and relative humidity data for all four schools in the IVSE study. The data are aggregated by Experimental (IHPAC) and Control (10 SEER) classrooms. Summertime school vacation schedules precluded inclusion of northern California data. See report text for explanation of box and whisker plot statistics. 
Improving Ventilation and Saving Energy: Relocatable Classroom Field Study Interim Report
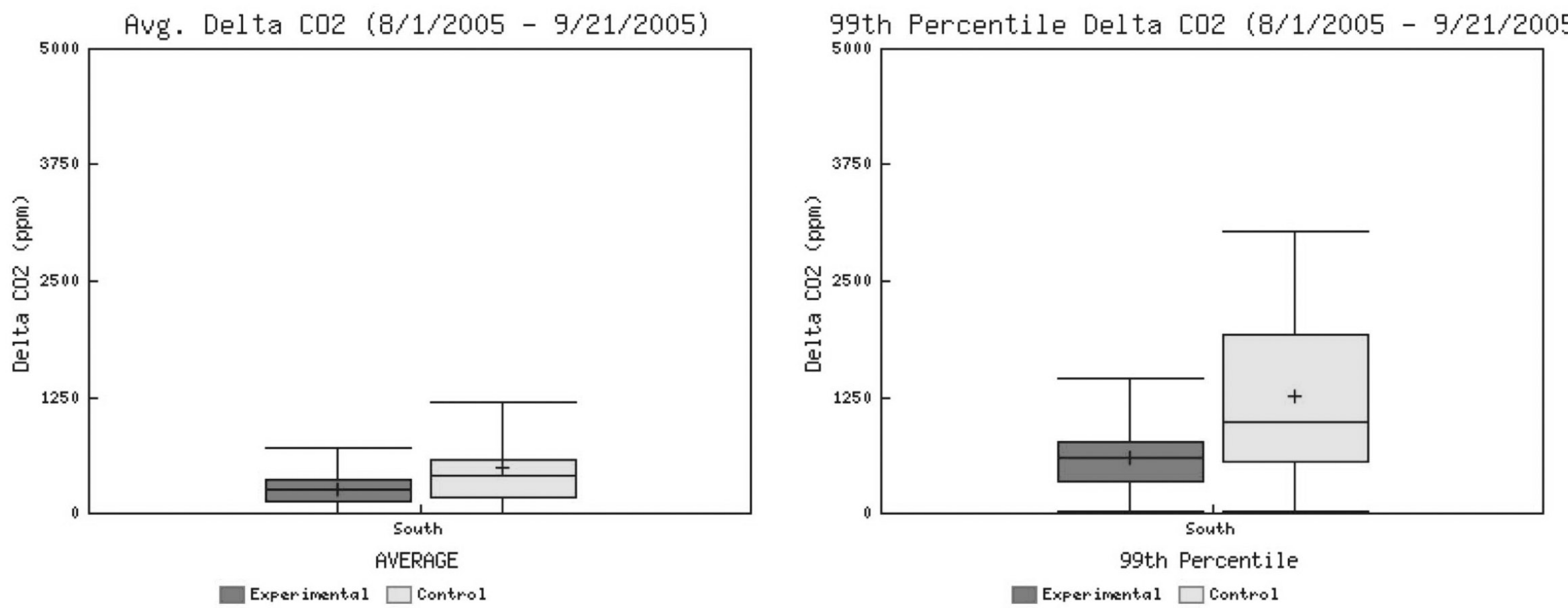

Figure 8. Box and whisker distributions of school day-average and $99^{\text {th }}$ daily percentile summertime (August 1 -September 21 ) indoor minus outdoor carbon dioxide data for two southern California schools in the IVSE study. The data are aggregated by Experimental (IHPAC) and Control (10 SEER) classrooms. Summertime school vacation schedules precluded inclusion of northern California data. See report text for explanation of box and whisker plot statistics. 
Improving Ventilation and Saving Energy: Relocatable Classroom Field Study Interim Report
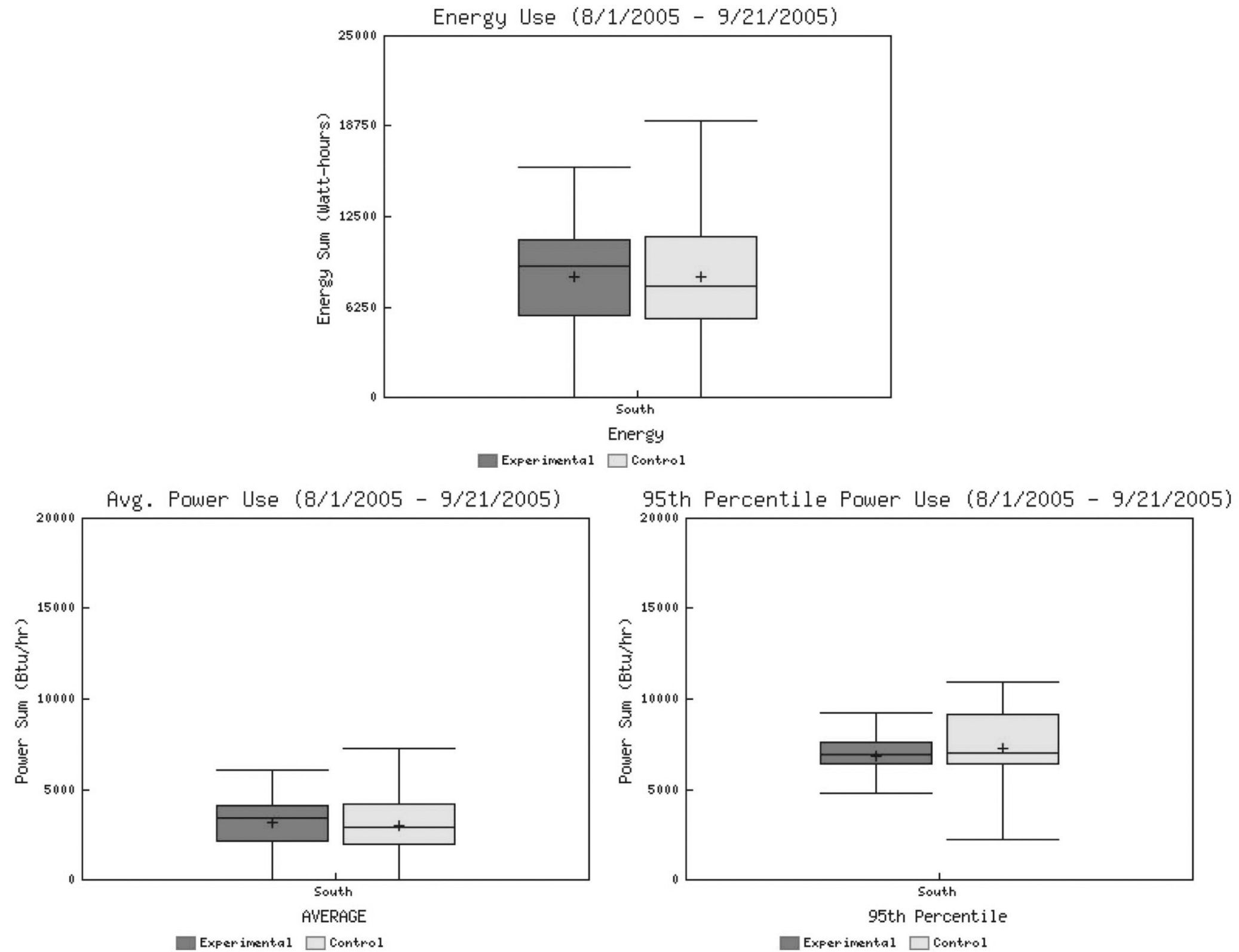

95th Percentile

Figure 9. Box and whisker distributions of school day-average summertime (August 1-September 21) energy use and daily average and $95^{\text {th }}$ percentile HVAC power consumption for all four schools in the IVSE study. The data are aggregated by Experimental (IHPAC) and Control (10 SEER) classrooms. Summertime school vacation schedules precluded inclusion of northern California data. See report text for explanation of box and whisker plot statistics. 


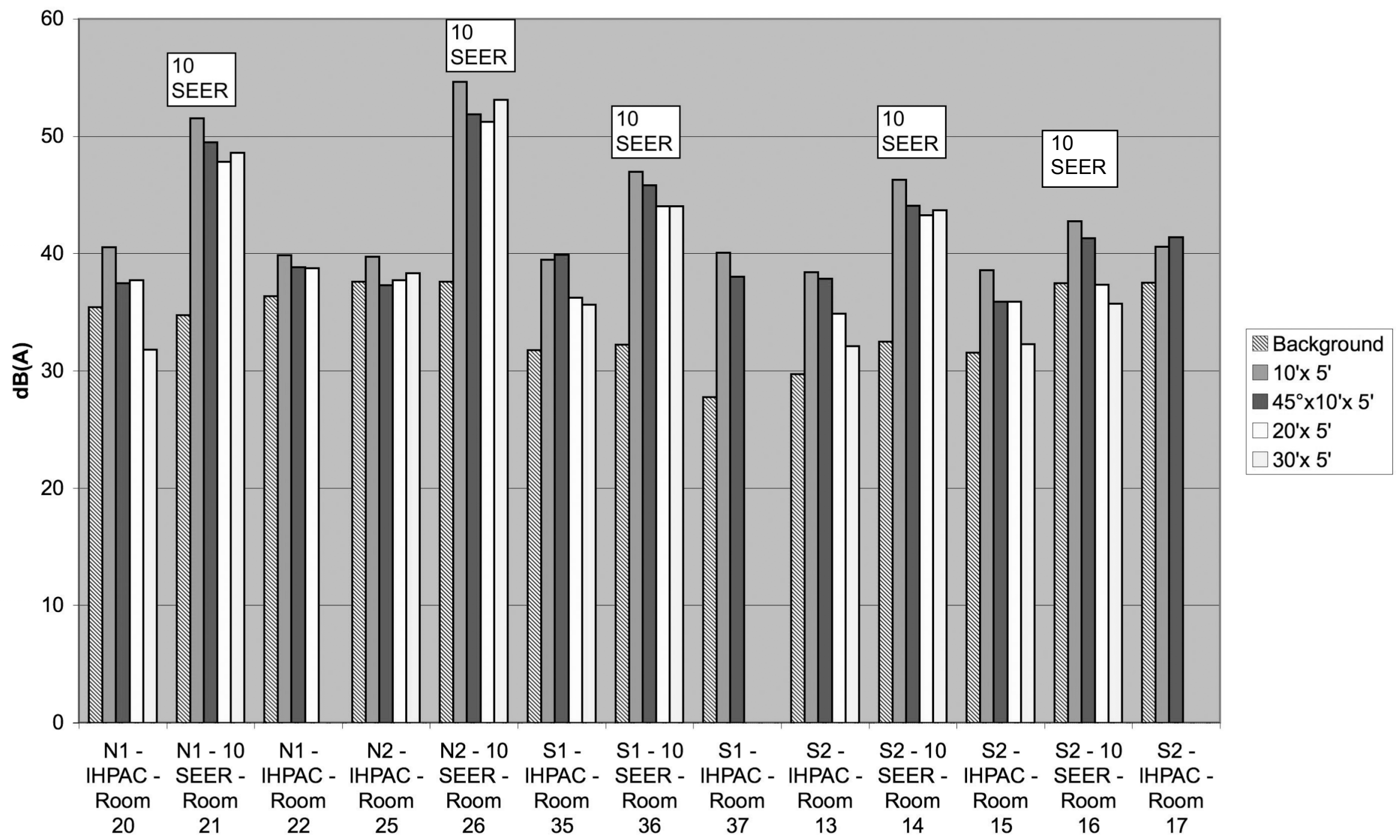

Figure 10. Indoor acoustic noise A-weighted sound pressure levels $(\mathrm{dB}(\mathrm{A}))$ in 13 unoccupied RCs equipped with either a 10 SEER HVAC system or an IHPAC HVAC system. Lights were off. HVAC system off (Background - all equipment off), or operated with only fan on, and measured at the locations described in the text (see legend). 


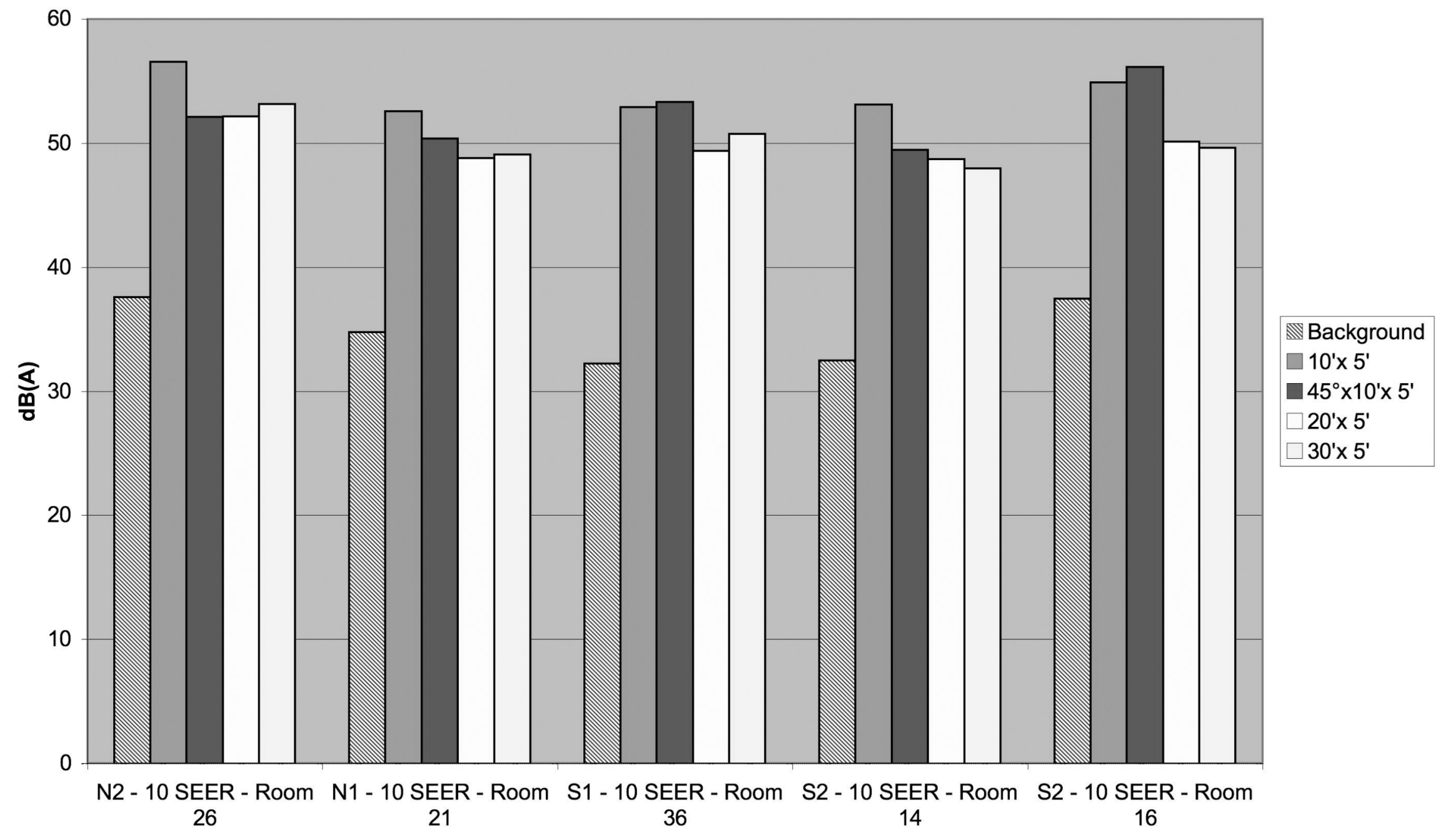

Figure 11. Indoor acoustic noise A-weighted sound pressure levels (dB(A)) in five RCs equipped with a 10 SEER HVAC system. Lights were off. HVAC system off (Background - all equipment off), or operated with fan and compressor on and measured at the locations described in the text (see legend). 


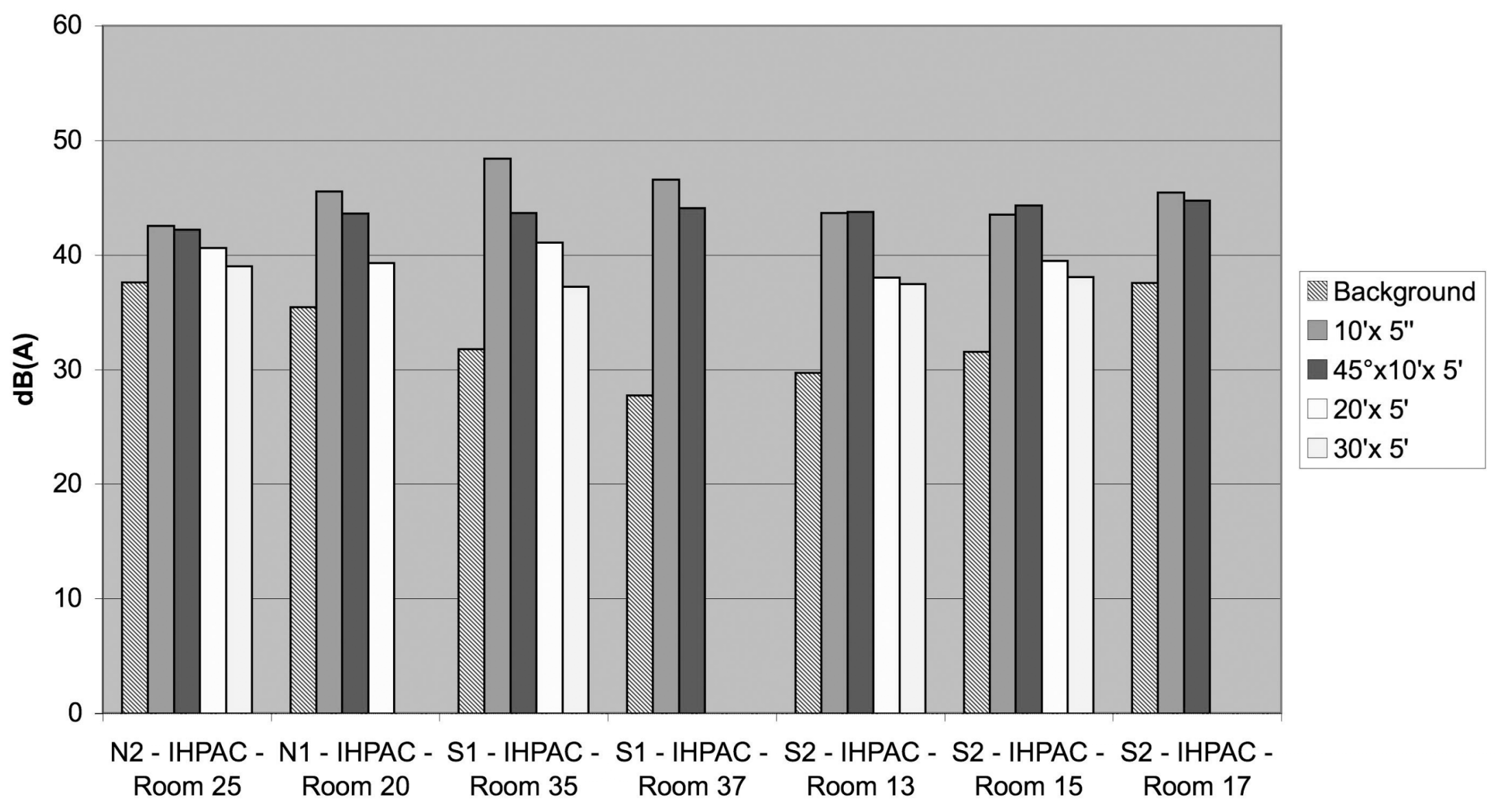

Figure 12. Indoor acoustic noise A-weighted sound pressure levels $(\mathrm{dB}(\mathrm{A}))$ in seven unoccupied RCs equipped with a IHVAC HVAC system. Lights were off. HVAC system off (Background - all equipment off), or operated with fan and compressor (Stage-1) on and measured at the locations described in the text (see legend). 


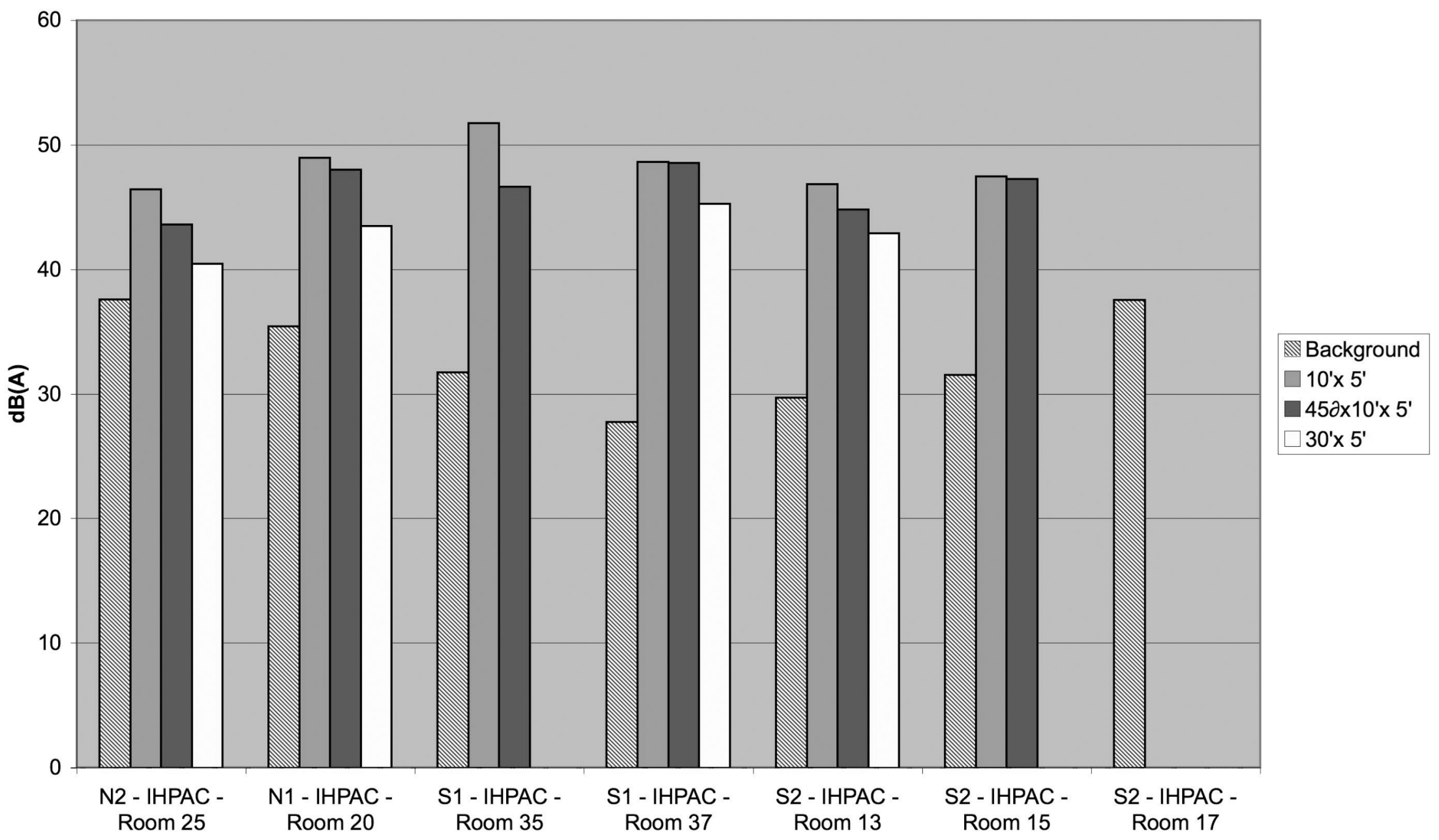

Figure 12. Indoor acoustic noise A-weighted sound pressure levels $(\mathrm{dB}(\mathrm{A}))$ in seven unoccupied RCs equipped with a IHVAC HVAC system. Lights were off. HVAC system off (Background - all equipment off), or operated with fan and compressor (Stage-2) on and measured at the locations described in the text (see legend). 